MIECZYSEAW WRZOSEK (Białystok)

\title{
PRZEKAZY ŹRÓDŁOWE DO DZIEJÓW POLSKIEGO RUCHU WOJSKOWEGO W ROSYJSKIEJ 2 ARMII (1917-1918)
}

\section{CZESŚĆ I}

Szanse rozwoju polskiego ruchu wojskowego w Rosji ujawniły się po obaleniu caratu i były bardzo duże. Wynikały one przede wszystkim z faktu, że wiosną 1917 r. w armii rosyjskiej służyło jeszcze około 500 tysięcy Polaków, w tym 119 generałów i prawie 20 tysięcy oficerów, przeważnie młodszych rangą. Formalna podstawę polskiego ruchu wojskowego stanowiły przepisy określające rewolucyjny status armii rosy jskiej. W zbiorze tych przepisów zasadniczą rolę odegrały takie dokumenty, jak: Tymczasowe zarządzenie o organizacji władz Armii Czynnej i Floty z 4 (17) marca 1917 r., wydane przez nowego głównodowodzącego generała Michała Aleksiejewa i rozkaz nr 114 ministra wojny Aleksandra Guczkowa z 5 (18) marca tegoż roku.

Oba wymienione tu dokumenty uwzględniały treść tak zwanego rozkazu nr 1, wydanego w dniu 1 (14) marca 1917 r. przez Piotrogrodzką Radę Delegatów Robotniczych i Żołnierskich (RDRiŻ). Jedno z jego sformułowań, mające zasadnicze znaczenie dla rozważań podejmowanych w niniejszym szkicu, zawierało polecenie dotyczące tworzenia w armii rosy jskiej komitetów żołnierskich. To właśnie polecenie zostało wykorzystane przez Polaków, którzy zaczęli tworzyć własne organizacje, określane jako związki wojskowe.

Początki polskiego ruchu wojskowego w Rosji datują się od 17 marca 1917 r. i wiążą się z powołaniem Związku Wojskowych Polaków (ZWP) w Piotrogrodzie. Wyjątkowo aktywnymi uczestnikami tego ruchu byli natomiast ci Polacy, którzy służyli w rosyjskiej 2 Armii, zmobilizowanej na obszarze Warszawskiego Okręgu Wojskowego i zaliczonej w skład wojsk 
Frontu Zachodniego. Jego siłami dowodził generał Anton Denikin, który miał w swej dyspozycji ponadto 3 Armię i 10 Armię.

Decyzja w sprawie powołania ZWP 2 Armii zapadła w dniu 5 (18) kwietnia 1917 r. Została podjęta przez uczestników zebrania, w którym mieli prawo brać udział wszyscy Polacy zakwaterowani w Nieświeżu i pełniący tam służbę w jednostkach podporządkowanych bezpośrednio sztabowi armii. Doszło również do powołania komitetu organizacyjnego w składzie: sztabsrotmistrz Miniszewski, chorąży Czesław Wolff, chorąży Szymański, urzędnik wojskowy Stanisław Zieliński, starszy podoficer Gawor, młodszy podoficer Ryszard Krajewski i szeregowiec Józef Krycz. Ten siedmioosubowy zespół patronował następnie przygotowaniom do zebrania, które odbyło się 10 (23) kwietnia 1917 r. w nieświeskim klubie oficerskim Zarządu Generała Kwatermistrza 2 Armii i miało na celu głównie wybór delegatów na Zjazd Wojskowych Polaków Frontu Zachodniego w Mińsku Litewskim. W roli bezpośredniego organizatora obrad nieświeskich wystąpił natomiast podpułkownik Paweł Aleksandrowicz, a do stołu prezydialnego zostały powołane następujące osoby wojskowe: chorąży Szymański jako zastępca przewodniczącego, urzędnik wojskowy Stanisław Zieliński jako sekretarz, zaś w roli asesorów wystąpili podoficer Stanisław Lipno i starszy szeregowy Aleksander Kaczorkiewicz.

W toku obrad wybrano delegatów na wspomniany już zjazd Polaków służących w wojskach Frontu Zachodniego i uchwalono siedem wniosków programowych. Dotyczyły one: 1) utworzenia armii polskiej, 2) uksztaltowania armii polskiej jako samodzielnej siły zbrojnej wojsk Koalicji walczącej z państwami Czwórprzymierza, a przeznaczonej wyłącznie do działań zbrojnych na froncie niemiecko-austriackim, 3) dążenia do formowania armii polskiej złożonej $\mathrm{z}$ wszystkich rodzajów wojsk, 4) zachowania w okresie poprzedzającym formowanie armii polskiej ducha karności i porządku, 5) przyjmowania do szeregów armii polskiej wszystkich osób uważających się za Polaków, 6) poruszenia podczas obrad zjazdu frontowego kwestii dotyczących korespondencji z rodzinami w kraju, 7) wszczęcia starań o poprawę ciężkiej doli jeńców Polaków przebywających w niewoli rosy jskiej.

Uzgodnione postulaty spotkały się $\mathrm{z}$ aprobatą uczestników zjazdu frontowego, który trwał od 29 kwietnia do 4 maja 1917 r., a upamiętnił swoje obrady uchwaleniem statutu przeznaczonego dla ZWP Frontu Zachodniego, pomyślanego $\mathrm{w}$ tym dokumencie jako zrzeszenie obejmujące ogół Polaków służących w szeregach wojsk tegoż frontu. W konkretnych zadaniach projektowanego stowarzyszenia brano pod uwagę ponadto: wytworzenie łączno- 
ści na gruncie kulturalno-narodowym między Polakami wojskowymi i wzajemną pomoc; uświadamianie, podnoszenie i utrwalanie ducha narodowego oraz przygotowywanie członków związku do pracy obywatelskiej w kraju, a także szerzenie oświaty w środowiska.ch żołnierskich; udzielania, członkom związków informacji i porad prawnych; ułatwianie korespondencji z rodzinami w kraju i na, wygnaniu; wreszcie roztaczanie opieki nad inwalidami, rannymi i jeńcami, a także pośredniczenie w poszukiwaniu pracy i udzielanie zapomóg.

Związek frontowy został zaprojektowany jako organizacja złożona z członków rzeczywistych, w poczet których zamierzano przyjmować osoby wojskowe (oficerów służby czynnej i rezerwy, żołnierzy, lekarzy, farmaceutów, urzędników wojskowych, kapelanów, junkrów i siostry miłosierdzia), członków popierających (osoby nie służące w wojsku, ale aprobujące cele związku), a także członków honorowych, powoływanych przez walne zgromadzenia na propozycje zarządu.

Zakładanej organizacji związkowej nadano charakter zrzeszenia o hierarchicznej strukturze wewnętrznej. Przewidziano mianowicie powołanie zarządu koordynującego ruch związkowy w wojska.ch całego Frontu Zachodniego, a także zarządów armijnych, dywizy jnych i oddziałowych (pułki, samodzielne bataliony i dywizjony, samodzielne kompanie, zakłady tyłowe i szpitale).

Po zjeździe mińskim ruch związkowy ogarnął formacje wojskowe Frontu Zachodniego. W 2 Armii na jego czele stanął Tymczasowy Komitet Wykonawczy związków wojskowych i rozpoczął swoją działalność pod kierunkiem podpułkownika Aleksandrowicza z Oddziału Wywiadowczego sztabu armii. Struktura związków przewidywała trzy płaszczyzny działania.. Na. poziomie najniższym miały funkcjonować podstawowe organizacje związkowe (filie), tworzone w oddziałach oraz jednostkach samodzielnych i zakładach tyłowych, a zrzeszające co najmniej pięciu Polaków służących w danej jedrıostce. Działalność filii koordynowały organy kolegialne, określane jako za.rządy dywizyjne. Było to określenie umowne, odnosiło się bowiem do organizacji zakła.danych nie tylko w dywizjach piechoty i kawalerii, lecz także w zespołach samodzielnych jednostek pozadywizyjnych, a. podlegających bezpośrednio dowódcom korpusów lub dowódcy 2 Armii. W wyniku dociekań opartych na. wzmianka.ch rozproszonych w przebadanej korespondencji udało się stwierdzić, że w 2 Armii było 13 zarządów dywizyjnych w ścisłym tego słowa. znaczeniu oraz 8 zarządów dywizy jnych w pojęciu umownym. Na, czele, czyli na płaszczyźnie najwyższej, jak to zostało już stwierdzone, stał początkowo Tymczasowy Komitet Wykonawczy związków. 
W dniu 18 lipca 1917 r., gdy ruch wojskowy w 2 Armii wyraźnie już okrzepł, zwierzchnictwo nad nim przejął stały zarząd centralny. W skład tego zarządu weszli: podpułkownik Paweł Aleksandrowicz jako prezes, urzędnik wojskowy Stanisław Zieliński (zastępca prezesa), szeregowy Donalis (drugi zastępca prezesa), chorąży Czesław Wolff (sekretarz) i starszy podoficer Gawor jako skarbnik, a ponadto czterech przedstawicieli korpusów (po jednym z każdego). Powołany zarząd, jak wynika $z$ raportów szczegółowych, reprezentował 6090 członków, którzy należeli do 160 organizacji związkowych. Na stanowiskach kierowniczych występowała znaczna liczba wojskowych niskiego stopnia, nawet szeregowych. Zadecydowało o tym, w znacznej mierze, zalecenie centralnego zarządu, który brał pod uwagę możliwość łatwiejszego oddelegowania takich właśnie osób do pracy w polskim ruchu wojskowym. Chodziło także o zachowanie pozorów demokratyzmu, ponieważ w armii rosyjskiej uzewnętrzniał się stały wzrost nastrojów rewolucyjnych.

Daleko idącą oględność okazywały również związki wojskowych Polaków 2 Armii w formułowaniu założeń ideowych, opieranych na statucie uchwalonym przez uczestników zjazdu mińskiego, a następnie na postanowieniach I Ogólnego Zjazdu Wojskowych Polaków w Piotrogrodzie, który obradował w dniach od 7 do 22 czerwca 1917 r., a zakończył się rozłamem i powołaniem dwóch central ogólnowojskowych, to znaczy Naczelnego Polskiego Komitetu Wojskowego (Naczpolu) oraz Komitetu Głównego Związków Wojskowych Polaków (lewicy). Oblicze ideowe związków 2 Armii uzewnętrzniało się w ich stosunku do ówczesnych wydarzeń, a konkretnie w stosunku do uczestników tych wydarzeń (pojedynczych osób, ugrupowań politycznych, instytucji wojskowych i cywilnych organów władzy rosyjskiej). Z czasem na czoło spraw wysunęła się sprawa polskiego wojska w Rosji.

W podejściu związków 2 Armii do tej sprawy dominowało na ogół stanowisko pozytywne, co sprawiło, że Związki te opowiadały się raczej przeciw Komitetowi Głównemu, który się bolszewizował coraz wyraźniej. Niektóre zrzeszenia, między innymi ZWP 75 Dywizji Piechoty działający pod kierunkiem lewicującego kapelana Jana Pajkerta, zajmowały jednak także wstrzemięźliwe stanowisko wobec Naczpolu. O takim stanowisku zadecydowało, być może, niezadowolenie spowodowane rozłamem, który narastał między Naczpolem a Komitetem Głównym i powodował w szeregach wojskowych Polaków szkodliwe rozdwojenie. Wysiłki na rzecz wzajemnego pojednania okazywały się jednak daremne.

Organy kierownicze polskiego ruchu wojskowego 2 Armii nie czuły się kompetentne do zajęcia pryncypialnego stanowiska w sprawach o charakterze międzynarodowym, ale i te kwestie nie były im obce. Świadczyły o tym 
celne wypowiedzi szeregowego Franciszka Kulikowskiego, który potrzebę rozbudowy polskiego wojska w Rosji kojarzył z perspektywą przyszłego kongresu pokojowego. Wielkie zaniepokojenie budziło również stanowisko Komitetu Organizacyjnego Sztokholmskiej Konferencji II Międzynarodówki, wyrażone w manifeście z 6 kwietnia 1917 r. W punkcie dotyczącym warunków przyszłego traktatu pokojowego autorzy manifestu, ulegając delegatom niemieckim, bąkali bowiem o zawężeniu terytoriów przyszłej, niepodległej Polski tylko do obszarów zaboru rosyjskiego, w dodatku znacznie okrojonego.

Zdecydowane stanowisko zajął polski ruch wojskowy 2 Armii również wobec propozycji pokojowych, sformułowanych przez Centralny Komitet Wykonawczy Piotrogrodzkiej RDRiŻ. Chodzi tu o warunki przekazane Matwiejowi Iwanowiczowi Skobielewowi, wydelegowanemu przez rząd rosyjski na paryską konferencję państw Koalicji. Postulat dotyczący sprawy polskiej w przekazanym mu dokumencie streszczał się w żądaniu ustąpienia niemieckich i austriackich wojsk tylko $\mathrm{z}$ tych terytoriów, które należały poprzednio do państwa rosyjskiego, co oznaczało, że przyłączenie ziem zaboru pruskiego i austriackiego do przyszłego państwa polskiego nie było brane pod uwagę. Stanowisko takie spotkało się więc $\mathrm{z}$ ostrym potępieniem działaczy związków wojskowych Polaków rosyjskiej 2 Armii, a sprawy te znajdują wyraźne odbicie w dokumentach załączonych do niniejszego szkicu i w publikowanym za tymi dokumentami opracowaniu. Z tych materiałów wynika również, że jesienią 1917 r. w polskim ruchu wojskowym 2 Armii zaczynał się ujawniać nurt rewolucyjny. Zjawisko to miało jednak charakter przejściowy i nie wpłynęło w sposób decydujący na postawę Polaków służących w formacjach 2 Armii. Oni też w znacznej mierze zasilili szeregi I Korpusu Polskiego generała Józefa Dowbor-Muśnickiego.

Publikowane materiały to komplet protokółów obrad podejmowanych podczas posiedzeń Tymczasowego Komitetu Wykonawczego Wojskowych Polaków 2 Armii i z posiedzeń powołanego później zwyczajnego Zarządu Związków Wojskowych Polaków tejże armii. Są to oryginalne rękopisy sporządzone ręką sekretarzy, podoficera Krassowskiego i urzędnika wojskowego Stanisława Zielińskiego. Dokumenty te mają dużą wartość naukową nie tylko dla spraw związanych $\mathrm{z}$ działalnością polskich związków wojskowych w 2 Armii, lecz także dla badań poświęconych dziejom ogólnym polskiego ruchu wojskowego w Rosji w latach 1917-1918. Protokóły są zabezpieczone w Centralnym Archiwum Wojskowym, w grupie zespołów określanych jako Związki Wojskowych Polaków w Rosji. W zespołach wymienionego archiwum występują pod sygnaturą: 122/100/66, s. 1-51. Wspomniane opraco- 
wanie, przygotowane przez porucznika Mieszkowskiego i zatytułowane przez niego jako Historia Zarzqdu Wojskowych Polaków Armii 2-giej, znajduje się również w zasobach $\mathrm{CAW}$, ale w grupie materiałów luźnych, określonych jako kolekcje. Jest więc dostępne pod następującą sygnaturą: Kolekcje, t. $400 / 1615$.

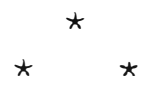

\section{Dokument nr 1}

1917 czerwiec 3, Nieśwież. - Protokót nr 1 pierwszego, nadzwyczajnego posiedzenia Tymczasowego Komitetu Wykonawczego Wojskowych Polaków Rosyjskiej 2 Armii.

Tymczasowy Komitet... postanowił.

1. Ogłosić zebranym ${ }^{1}$, że wszystkie zarządzenia Komitetu do czasu przyszłego zjazdu² powinny mieć bezwzględną moc prawną.

2. Polecić wszystkim zebranym delegatom, by niezwłocznie zorganizowali Polaków w swych oddziałach, na zasadach Statutu Frontowego ${ }^{3}$ i by skłonili drogą agitacji sąsiednie części do zorganizowania się, pomagając czynnie tej sprawie.

3. Komitet Wykonawczy ogłasza tymczasowy swój adres: „Zarząd Naczelnika Inżynierów Armii 2-giej, chorąży Czesław Wolff" i pod tym adresem prosi donosić o istniejcych i powstających związkach w częściach ze wskazaniem prezesa, liczby zorganizowanych osób i adresów związków, a także zwracać się do Tymczasowego Komitetu Wykonawczego w razie potrzeby.

Zastępca prezesa chorąży Wolff Sekretarz B. Krassowski

1 Chodzi o uczestniczących w zjeździe przedstawicieli Polaków służących w jednostkach rosyjskiej 2 armii. Obradowali oni w dniu 21 maja 1917 r.; podczas przerwy zarzadzonej w toku tych obrad odbyło się krótkie, nadzwyczajne posiedzenie, upamiętnione niniejszym protokołem.

2 Wzmianka dotyczy następnego, planowanego zjazdu.

3 Chodzi o statut Związku Wojskowych Polaków Frontu Zachodniego, czyli o dokument programowy uchwalony podczas zjazdu przedstawicieli wojskowych Polaków, którzy służyli w wojskach Frontu Zachodniego. Zjazd ten odbywał się w dniach od 29 kwietnia do 4 maja 1917 r. M. Wrzosek, Z dziejów polskiego ruchu wojskowego w rosyjskiej 2 armii w 1917 r., „Studia Śląskie”, seria nowa, t. XLII, 1983, s. 470. 


\section{Dokument nr 2}

1917 czerwiec 5, Nieśwież. - Protokót nr 3 posiedzenia zwyczajnego Tymczasowego Komitetu Wykonawczego Wojskowych Polaków Rosyjskiej 2 Armii.

Tymczasowy Komitet... postanowił.

1. Kooptować do składu Tymczasowego Komitetu Wykonawczego podpułkownika Aleksandrowicza ${ }^{1}$ uznając jego współudział w pracach Komitetu za niezbędny.

2. Wybór prezydium; jednogłośnie powołano:

a) na prezesa podpułkownika Aleksandrowicza;

b) na zastępcę prezesa chorążego Czesława Wolffa;

c) na sekretarza starszego podoficera Krassowskiego.

3. Polecono zawiadomić o powołaniu przez Zjazd Wojskowych Polaków 2 Armii, odbyty w dniu 21 maja 1917 roku, Tymczasowego Komitetu Wykonawczego i o ukonstytuowaniu takowego wyższe władze wojskowe armii 2-giej.

4. Polecono prezydium zwrócić się do odnośnych władz z prośbą o zalegalizowanie Tymczasowego Komitetu Wykonawczego Wojskowych Polaków armii 2-giej i o zezwolenie na używanie własnej pieczęci z napisem: „Tymczasowy Komitet Wykonawczy Wojskowych Polaków armii 2-giej".

5. Polecono prezydium wyjaśnić sprawę możliwości uzyskania funduszy rządowych na wydatki organizacyjne.

Zastępca prezesa chorąży Czesław Wolff Sekretarz B. Krassowski

1 Podpułkownik Paweł Aleksandrowicz na przełomie marca i kwietnia 1918 r. był współorganizatorem władz cywilnych obszaru kontrolowanego przez wojska generała Józefa Dowbor-Muśnickiego. Stał na czele Zarządu Administracyjnego, który zajmował się administracją ziemską i wiejską, oświatą oraz sprawami sanitarnymi i prawno-sądowymi. M. Wrzosek, Polskie korpusy wojskowe w Rosji w latach 1917-1918, Warszawa 1969, s. 32 . 


\section{Dokument nr 3}

1917 czerwiec 6, Nieśwież. - Protokót nr 3 posiedzenia zwyczajnego Tymczasowego Komitetu Wykonawczego Wojskowych Polaków Rosyjskiej 2 Armii.

Tymczasowy Komitet... postanowił.

1. Przyjąć zaproponowany przez chorążego Czesława Wolffa i przez niego odczytany komunikat do władzy wyższej armii 2-giej oraz projekt rozkazu wojskom armii 2-giej i polecono go wysłać dokąd należy.

2. Polecić porucznikowi Wolffowi jako delegatowi na zjazd Wojskowych Polaków armii 2-giej, odbyty w dniu 21 maja roku bieżącego od Zarządu Oddzielnego Kierownika Robót ${ }^{1} 3$ ucząstku $^{2}$ Zachodniego Frontu, bezpośrednio lub przez osoby upełnomocnione, porozumieć się ze wszystkimi częściami ${ }^{3}$ Grukozapa $^{4}$ 3-go w celu zawiązania w każdej części Związku Wojskowych Polaków na podstawie Statutu Frontowego i polecić złączenie powstałych związków w centralę przy Zarządzie Grukozapa.

3. O każdym powstałym związku oraz centrali należy zawiadomić Tymczasowy Komitet Wykonawczy ze wskazaniem ilości zorganizowanych członków oraz osoby stojącej na czele związków i centrali.

4. Polecić prezydium zakomunikować Związkowi Wojskowych Polaków Frontu Zachodniego o powołaniu przez Zjazd Wojskowych Polaków Armii 2-giej odbyty w dniu 21 maja roku bieżącego Tymczasowego Komitetu Wykonawczego Wojskowych Polaków Armii 2-giej ze wskazaniem prezydium i adresu.

5. O tym samym polecić zawiadomić Komitet Wykonawczy Armii 2-giej (rosyjski) i Komitet Wykonawczy Załogi Nieświeskiej

Zastępca prezesa chorąży Czesław Wolff Sekretarz B. Krassowski

1 W określeniach „Oddzielnego Kierownictwa Robót” chodzi o Samodzielne Kierownictwo Robót.

2 Zamiast rusycyzmu: „ucząstka” powinno być odcinka.

3 Zamiast słowa „częściami” winno być jednostkami.

4 Słowo Grukozap jest skrótem wyrazów: Gławnoje Rukowodstwo Zapadnowo Fronta, a zatem chodzi o Główne Kierownictwo Frontu Zachodniego. 


\section{Dokument nr 4}

1917 czerwiec 8, Nieśwież. - Protokót nr 4 posiedzenia zwyczajnego Tymczasowego Komitetu Wykonawczego Wojskowych Polaków Rosyjskiej 2 Armii.

Tymczasowy Komitet... postanowił.

1. Wysłać telegram na imię Prezesa Zjazdu Wojskowych Polaków1.

2. Zwrócić się do inżynierów Radzikowskiego i Nestorowicza w celu zorganizowania Polaków pracujących w drogowych oddziałach armii 2-giej na zasadach Statutu Frontowego w sposób następujący: a) zawiązać związek Polaków w każdym oddziale i transporcie ${ }^{2}$ pod kierunkiem prezesa, sekretarza, skarbnika i bibliotekarza; b) przy Zarządzie utworzyć komitet centralny, członkami którego są prezesi poszczególnych związków; c) Komitet centralny obiera prezydium, które stale urzęduje przy Zarządzie Robót Drogowych. Komitet centralny ma prawo kooptacji; d) polecić prezydium centralnego komitetu bezpośrednio komunikować się z Tymczasowym Komitetem Wykonawczym Wojskowych Polaków Armii 2-giej i donosić o ilości związków, ilości zorganizowanych w nich osób i składzie zarządu.

3. Zwrócić się do Zarządu Hydrotechnicznego przy sztabie armii 2-giej w tejże sprawie organizacji hydrologicznych oddziałów na tychże samych zasadach.

4. Polecić prezesowi Związku Wojskowych Polaków Zarządu Naczelnika Inżynierów Armii 2-giej zorganizowanie związków wojskowych Polaków w częściach podlegających naczelnikowi inżynierów armii 2-giej i utworzenie komitetu centralnego przy zarządzie na wyżej wyuszczonych podstawach (punkt 2).

5. W celu uzyskania funduszy na wydatki organizacy jne związane $z$ działalnością Tymczasowego Komitetu Wykonawczego upoważnić do zbierania dobrowolnych składek chętne ku temu osoby.

6. Polecić sekretarzowi nabyć niezbędne księgi, papiery itp. dla kancelarii Tymczasowego Komitetu Wykonawczego.

7. Powołać do kancelaryjnych prac płatnego biuralistę.

Zastępca prezesa chorąży Czesław Wolff Sekretarz B. Krassowski

1 Chodzi o prezesa Naczelnego Polskiego Komitetu Wojskowego (Naczpolu) chorażego Władysława Raczliewicza.

2 W stwierdzeniu o "transporcie" chodzi o jednostkę transportowa. 


\section{Dokument nr 5}

1917 czerwiec 11, Nieśwież. - Protokót nr 5 posiedzenia zwyczajnego Tymczasowego Komitetu Wykonawczego Wojskowych Polaków Rosyjskiej 2 Armii.

Tymczasowy Komitet... postanowił.

1. Polecić starszemu podoficerowi Gaworowi skomunikować się z podkapitanem ${ }^{1}$ Klimenko w sprawie wyjaśnienia, jakie rozporządzenie dał dowódca armii na skutek podania o zalegalizowanie Tymczasowego Komitetu i wydaniu zapomogi oraz prosić o wydanie spisu wszystkich części wojskowych, gdzie są Polacy.

2. Polecić Sekretarzowi rozesłać protokóły ze zjazdu w dniu 21 maja 1917 roku odbytego do wszystkich części wojskowych reprezentowanych na zjeździe.

3. Polecić chorążemu Wolffowi opracować projekt odezwy do wszystkich Polaków armii 2-giej z wezwaniem do organizowania się według wskazanego schematu, dla bezpośredniej łączności z Tymczasowym Komitetem Wykonawczym.

Zastępca prezesa chorąży Czesław Wolff Sekretarz B. Krassowski

1 W tekście dokumentu znajduje się określenie podkapitan; winno być sztabskapitan.

\section{Dokument nr 6}

1917 czerwiec 15, Nieświez. -- Protokót nr 5 posiedzenia zwyczajnego Tymczasowego Komitetu Wykonawczego Wojskowych Polaków Rosyjskiej 2 Armii.

Tymczasowy Komitet... postanowił.

1. Obstalować druki z nagłówkiem Tymczasowego Komitetu oraz adresem prostym i telegraficznym w ilości 500 sztuk różnych formatów.

2. Polecić chorążemu Powierra i podoficerowi Góreckiemu zorganizować centralny Związek przy 2-gim Awiacyjnym Dywizjonie wszystkich awiacyjnych oddziałów armii.

3. Zapytać chorążego Józefa Ściegosza, będącego na służbie w 257-mym 
Wojenny $\mathrm{m}^{1}$ Transporcie o stanie organizacji w transportowych częściach armii; gdyby takowa organizacja nie istniała polecić mu wespół $\mathrm{z}$ chorążym 256 Transportu Gątkiewiczem powołanie do życia Centralnego Komitetu Wojskowych Polaków przy transportowej części armii na wiadomych zasadach.

4. Kooptować urzędnika XV Inżynieryjnej Brygady Zielińskiego ${ }^{2}$ oraz starszego podoficera Cecha do składu komitetu uznając ich obecność za wielce dla Tymczasowego Komitetu pożyteczną wobec wyjazdu na urlop chorążego Szymańskiego i starszego podoficera Krassowskiego.

5. Wpisywać do protokółów nazwiska nie przybyłych na posiedzenie Tymczasowego Komitetu Wykonawczego członków.

Zastępca prezesa chorąży Czesław Wolff Za sekretarza A. Górecki

1 Słowo wojennym jest rusycyzmem; powinno być: wojskowym.

2 Chodzi o Stanisława Zielińskiego.

\section{Dokument nr 7}

1917 czerwiec 16, Nieśwież. - Protokót nr 7 posiedzenia zwyczajnego Tymczasowego Komitetu Wykonawczego Wojskowych Polaków Rosyjskiej 2 Armii.

Tymczasowy Komitet... postanowił.

1. Stwierdzić nieobecność kooptowanego członka Tymczasowego Komitetu Wykonawczego urzędnika Zielińskiego.

2. Przyjąć jednogłośnie odezwę do wszystkich Polaków armii 2-giej, zredagowaną i odczytaną przez chorążego Wolffa i wydrukować ją w 1000 egzemplarzach.

3. Wobec wyjazdu sekretarza komitetu starszego podoficera Krassowskiego powołać na to stanowisko urzędnika Zielińskiego.

4. Polecić starszemu podoficerowi Gaworowi przystąpić do organizacji niezorganizowanych jeszcze poszczególnych oddziałów sztabu armii na przyjętych ogólnych zasadach i wytworzenia ogólnej organizacji sztabu armii.

Zastępca prezesa chorąży Czesław Wolff Za sekretarza A. Górecki 


\section{Dokument nr 8}

1917 czerwiec 22, Nieśwież. - Protokót nr 8 posiedzenia zwyczajnego Tymczasowego Komitetu Wykonawczego Wojskowych Polaków Rosyjskiej 2 Armii.

Tymczasowy Komitet... postanowił.

1. Stwierdzić nieobecność sekretrza urzędnika Zielińskiego i starszego podoficera Gawora, który nieprzybycie swe usprawiedliwił chorobą.

2. Wydrukowane w 1000 egzemplarzy odezwy do wszystkich Polaków wojskowych armii 2-giej przesłać w pierwszym rzędzie do części wchodzących w skład dywizji.

3. Wydać nową odezwę w sprawie zorganizowania wszystkich oddziałów nie należących do dywizji.

4. Zapytać piśmiennie podkapitana Klimenko o rezultat starań w sprawie legalizacji działalności tegoż przez wydanie rozkazu do wojsk armii 2-giej, jak również w sprawie otrzymania zapomogi pieniężnej na cele komitetu.

Zastępca prezesa chorąży Czesław Wolff Za sekretarza A. Górecki

\section{Dokument nr 9}

1917 czerwiec 30, Nieśwież. - Protokót nr 9 posiedzenia zwyczajnego Tymczasowego Komitetu Wykonawczego Wojskowych Polaków Rosyjskiej 2 Armii.

Tymczasowy Komitet... postanowił.

1. Stwierdzić przybycie z Ogólnego Zjazdu Wojskowych Polaków w Piotrogrodzie prezesa komitetu podpułkownika Aleksandrowicza, który po powrocie objął kierownictwo sprawami komitetu i zaakceptował dotychczasową działalność zastępcy prezesa chorążego Czesława Wolffa i członków komitetu.

2. Stwierdzić przybycie starszego podoficera Krassowskiego i nieobecność członka komitetu żołnierza Donalisa.

3. Uznać za usprawiedliwioną nieobecność urzędnika wojskowego Zielińskiego na posiedzeniach komitetu w dniach 3 i 9 czerwca. 
4. Zwołać na dzień 15 lipca starego stylu ogólny zjazd delegatów wojskowych Polaków armii 2-giej.

5. Przy jąć opracowaną przez chorążego Czesława Wolffa odezwę do Polaków wojskowych znajdujących się w korpusowych i sztabowych oddziałach armii 2-giej i wydrukować ja w 1500 egzemplarzach.

6. Wydelegować dnia 19 czerwca podpułkownika Aleksandrowicza i chorążego Wolffa do dowódcy armii celem oświetlenia zadań i działalności Tymczasowego Komitetu Wykonawczego.

7. Rozsyłać odezwy i komunikaty Tymczasowego Komitetu Wykonawczego Naczelnemu Komitetowi Wykonawczemu w Piotrogrodzie, związkowi frontowemu w Mińsku oraz związkom wszystkich armii.

8. Zwrócić się do redakcji wszystkich pism polskich z prośbą o ogłoszenie adresu Tymczasowego Komitetu Wykonawczego.

9. Rozesłać statut związku frontowego delegatom uczestniczącym w zjeździe dnia 21 maja.

10. Następne posiedzenie komitetu zwołać dnia 20 czerwca o godzinie 9 -tej wieczorem.

Prezes podpułkownik Aleksandrowicz Zastępca prezesa chorąży Czesław Wolff Sekretarz Stanisław Zieliński

\section{Dokument nr 10}

1917 lipiec 3, Nieśwież. - Protokót nr 10 posiedzenia zwyczajnego Tymczasowego Komitetu Wykonawczego Wojskowych Polaków Rosyjskiej 2 Armii.

Tymczasowy Komitet... postanowił.

1. Przyjąć do wiadomości, że dowódca armii dla braku czasu nie mógł przyjąć dnia 19-go bieżącego miesiąca podpułkownika Aleksandrowicza i chorążego Wolffa.

2. Polecić wezwanemu przez Naczelny Komitet Wykonawczy Wojskowy w Piotrogrodzie kapitanowi Jaźwińskiemuํㅜ wobec zamierzonego spolonizowania L Armijnego Korpusu przez wlanie do szeregów tegoż w czasie najbliższym 18000 żołnierzy polskiego zapasowego pułku piechoty ${ }^{2}$, jak najszybsze zajęcie się sprawą mianowania na stanowisko dowódcy korpusu jenerała Polaka i obsadzenie wyższych stanowisk przez Polaków; wskazać Naczelnemu Komitetowi Wykonawczemu na potrzebę: a) uformowania w pierwszym rzę- 
dzie na Froncie Zachodnim co najmniej trzech korpusów polskich przy czym wyrażono życzenie, aby korpusy te weszły w skład armii 2-giej jako utworzonej w Warszawie i posiadającej w szeregach swoich wielu wojskowych Polaków; b) utworzenie na Froncie Zachodnim polskich pułków zapasowych.

3. Wydrukowane w 1500 egzemplarzach odezwy rozesłać do wszystkich oddziałów wojskowych armii 2-giej.

4. Przy jąć do wiadomości o zorganizowaniu Zarządu Centralnego Związków Wojskowych Polaków 129 Dywizji Piechoty z przedstawicielem porucznikiem Brzozowskim i zastępcą pisarzem Kwaśniewskim na czele.

5. Następne posiedzenie komitetu zwołać dnia 22 czerwca o godzinie 9 wieczorem.

Prezes podpułkownik Aleksandrowicz Zastępca prezesa chorąży Czesław Wolff Sekretarz urzędnik wojskowy Stanisław Zieliński

1 Chodzi o kapitana Bolesława Jaźwińskiego, późniejszego dowódcę 11 Dywizji Piechoty Wojska Polskiego, która w sierpniu 1920 r. uczestniczyła w walkach pod Radzyminem.

2 Chodzi o zapasowy pułk Dywizji Strzelców Polskich, który był rozlokowany w Biełgorodzie na Ukrainie i tam najpierw zrewolucjonizował się latem 1917 r., a potem nie chciał występować jako jednostka I Korpusu Polskiego pod dowództwem generała Józefa Dowbor-Muśnickiego. Pułk ten nie miał 18 tysięcy żołnierzy, ale ich liczba dochodziła do 17 tysięcy. Znaczna ich część w pierwszych miesiącach 1918 r. opowiedziała się po stronie rewolucji bolszewickiej i potem ci obałamuceni nieszczęśnicy występowali zbrojnie przeciw polskiej Ojczyźnie podczas wojny polsko-sowieckiej. Zob.: M. Wrzosek, $Z$ dziejów 1 Rewolucyjnego Putku Polskiego w Rosji 24 I 1917 - 6 I 1918 r., „Wojskowy Przegląd Historyczny" 1977, nr 3, s. 48-72; tegoż, Wojny o granice Polski Odrodzonej 1918-1921, Warszawa 1992, ss. 376.

\section{Dokument nr 11}

1917 lipiec 5, Nieśwież. - Protokót nr 11 posiedzenia zwyczajnego Tymczasowego Komitetu Wykonawczego Wojskowych Polaków Rosyjskiej 2 Armii.

Tymczasowy Komitet... postanowił.

1. Wobec wyjazdu starszego podoficera Gawora, o czym tenże zawiadomił Tymczasowy Komitet Wykonawczy nieobecność jego uznać za usprawiedliwioną.

2. Przyjąć do wiadomości oświadczenie podpułkownika Aleksandrowicza i chorążego Wolffa, że dowódca armii ze względów zasadniczych nie może 
ogłosić rozkazu do wojsk armii o ukonstytuowaniu się Tymczasowego Komitetu Wykonawczego oraz też wyasygnować 200 rubli na potrzeby komitetu, lecz oznajmił, że komitet ma zupełną swobodę działania i może liczyć na jego poparcie.

3. Wobec polonizowania L Armijnego Korpusu oraz 169 i 171 Dywizji Piechoty i rozporządzeń w tym kierunku Generalnego Sztabu sprzecznych z uchwała zjazdu w Piotrogrodzie, zwrócić się do Naczelnego Komitetu Wykonawczego z prośbą o poczynienie starań w celu zmiany sposobu formowania wspomnianych jednostek bojowych i natychmiastowego obsadzenia wyższych stanowisk przez Polaków.

4. Wobec dokonywania rewizji wojskowych w oddziałach sztabu armii w celu wcielenia do szeregów bojowych zdolnych do noszenia broni, zwrócić się do odpowiednich władz z żądaniem skierowania wydzielonych z oddzialów tyłowych Polaków do pułków zapasowych polskich.

5. Przy jąć do wiadomości, że odezwy do wojskowych Polaków zostały rozesłane.

6. Polecić sekretarzowi załatwienie bieżącej korespondencji w myśl postanowień komitetu.

7. Następne posiedzenie komitetu zwołać dnia 27 czerwca o godzinie 9 wieczorem.

Prezes podpułkownik Aleksandrowicz

Zastępca prezesa chorąży Czesław Wolff

Sekretarz urzędnik wojskowy Stanisław Zieliński

\section{Dokument nr 12}

1917 lipiec 11, Nieśwież. - Protokót nr 12 posiedzenia zwyczajnego Tymczasowego Komitetu Wykonawczego organizacji Wojskowych Polaków Rosyjskiej 2 Armii.

Tymczasowy Komitet... postanowił.

1. Nie przy jąć rezygnacji starszego podoficera Krassowskiego ze stanowiska członka Tymczasowego Komitetu Wykonawczego, a nieobecność jego na dzisiejszym posiedzeniu wobec nadmiaru pracy uznać za usprawiedliwiona.

2. Przy jać do wiadomości o zorganizowaniu Zarządu centralnego Związków Wojskowych Polaków Grenadierskiego Korpusu.

3. Zwrócić się do naczelnika sztabu 15 Syberyjskiej Strzeleckiej Dywizji o nie czynienie przeszkód Polakom dywizji przy organizacji związków. 
4. Wydrukować w 3000 egzemplarzy uchwały Pierwszego Ogólnego Zjazdu Wojskowych Polaków w Piotrogrodzie z dnia 6/19 czerwca roku bieżącego i otrzymane od Polskiego Komitetu Narodowego (Piotrogród, Praska 27 m 1) 500 egzemplarzy tychże uchwał rozesłać do wszystkich oddziałów wojskowych.

5. Zaprenumerować tygodniki „Wiadomości Wojskowe” i „Armia Polska".

6. Następne posiedzenie komitetu zwołać dnia 30 czerwca o godzinie 8.30 wieczorem.

Prezes podpułkownik Aleksandrowicz Zastępca prezesa chorąży Czesław Wolff

Sekretarz urzędnik wojskowy Stanisław Zieliński

\section{Dokument nr 13}

1917 lipiec 13, Nieświez. - Protokót nr 13 posiedzenia zwyczajnego Tymczasowego Komitetu Wykonawczego Wojskowych Polaków Rosyjskiej 2 Armii.

Tymczasowy Komitet... postanowił.

1. Uznając za pożądane utrzymanie kontaktu z komitetami wojskowymi rosyjskimi zwrócić się do Naczelnego Komitetu Wykonawczego z prośbą o włączenie do statutu paragrafu przewidującego taki kontakt.

2. Dla utrzymania kontaktu z Komitetem Wykonawczym Armii 2-giej (Ispołnitielnyj Komitet 2-roj Armii) zwrócić się doń z propozycją udzielenia wstępu na posiedzenia wspomnianego komitetu z głosem doradczym przedstawicielowi Tymczasowego Komitetu Wykonawczego pozostawiając ze swej strony Komitetowi Wykonawczemu 2-giej Armii, o ile on uzna za stosowne, prawo delegowania swego przedstawiciela na posiedzenia Tymczasowego Komitetu Wykonawczego organizacji wojskowych Polaków Armii 2-giej.

3. Wobec depeszy Wojennego Ministra nr 294, wzbraniającej chwilowo urządzania zjazdów, zawiadomić wojskowych Polaków armii 2-giej, że zjazd wojskowych Polaków armii 2-giej, projektowany na dzień 15 lipca starego stylu w terminie oznaczonym odbyć się nie może.

4. Zwrócić się do przedstawiciela transportów chorążego Ścięgosza z zawiadomieniem, że Tymczasowy Komitet Wykonawczy, wobec utworzenia w tyłowych oddziałach wojskowych komisji wojskowych mających na celu wcielenie do szeregów zdolnych do noszenia broni, zwrócił się do dowódcy 
armii z prośbą o wydanie rozkazu wstrzymującego wydzielenie wojskowych Polaków do czasu formowania oddziałów wojskowych polskich; Tymczasowy Komitet Wykonawczy zaleca wojskowym Polakom znajdującym się na służbie w transportach nie zapisywać się chwilowo w szeregi polonizowanych 169 i 171 Dywizji Piechoty, aby umożliwić w pierwszym rzędzie przeniesienie się do wskazanych dywizji Polakom znajdującym się w okopach.

5. Zwrócić się do dowódcy armii 2-giej z prośbą o wydanie rozkazu w sprawie rozciągnięcia uchwały Rady Wojennej z dnia 20 kwietnia roku bieżącego o dietach na delegatów uczestniczących w zjazdach wojskowych Polaków.

6. Wystosować okólniki do najliczniejszych związków wojskowych Polaków $\mathrm{w}$ dywizjach i korpusach, aby $\mathrm{w}$ porozumieniu $\mathrm{z}$ istniejącymi juz w danych jednostkach dywizyjnych i korpusowych związkami zorganizowały zarząd centralny pracujący nad wytworzeniem związków w oddziałach niezorganizowanych.

8. Zaprosić na posiedzenie Tymczasowego Komitetu Wykonawczego kooptowanego członka Tymczasowego Komitetu Wykonawczego starszego podoficera Cecha prosząc go w wypadku, gdyby w pracach Tymczasowego Komitetu Wykonawczego nie mógł przyjąć udziału, zawiadomić o tym komitet.

9. Następne posiedzenie Tymczasowego Komitetu Wykonawczego zwołać dnia 5 lipca o godzinie 8.30 wieczorem.

Prezes podpułkownik Aleksandrowicz Zastępca prezesa chorąży Czesław Wolff Sekretarz urzędnik wojskowy Stanisław Zieliński

\section{Dokument nr 14}

1917 lipiec 18, Nieśwież. - Protokót nr 14 posiedzenia zwyczajnego Tymczasowego Komitetu Wykonawczego Wojskowych Polaków Rosyjskiej 2 Armii.

Tymczasowy Komitet... postanowił.

1. Wydawać co tydzień w poniedziałek biuletyny Tymczasowego Komitetu Wykonawczego. Redagowanie biuletynów polecić Komisji Redakcyjnej, złożonej z trzech członków, za których podpisem biuletyny będą rozsyłane wszystkim oddziałom wojskowym armii 2-giej. Do Komisji Redakcyjnej weszli: podpułkownik Aleksandrowicz, chorąży Wolff i starszy podoficer Kras- 
sowski. Treść pierwszego biuletynu wydanego na mocy porozumienia telefonicznego chorążego Wolffa z członkami Tymczasowego Komitetu Wykonawczego zaakceptować.

2. W sprawie wypełnienia i podpisania deklaracji nadesłanej przez Zarząd Centralny Związków Wojskowych Polaków w Piotrogrodzie treści następującej: „Związek Wojskowych Polaków... niniejszym zawiadamia, iż przyłączając się do uchwał powziętych na Ogólnym Zjeździe Polaków Wojskowych w Piotrogrodzie, wyłoniony przez tenże zjazd Naczelny Polski Komitet Wojskowy za jedynego prawowitego przedstawiciela wszystkich wojskowych Polaków i dyrektywy tegoż zarządu uważa dla naszego związku za obowiązujące; postanowiono: Tymczasowy Komitet Wykonawczy, jako organ tymczasowy, mający na celu wyłącznie pracę organizacyjną, wspomnianej instrukcji w imieniu wojskowych Polaków armii 2-giej podpisać nie może, nie mając na to pełnomocnictwa. Z drugiej strony, uznając niezbędne wypełnienie zleceń nadsyłanych Tymczasowemu Komitetowi Wykonawczemu przez instytucje naczelne, Tymczasowy Komitet Wykonawczy zaleca prezydium przesłanie deklaracji związkom wojskowych Polaków z umieszczeniem w nagłówku deklaracji nazwy poszczególnego związku przy czym związki winne podpisane lub też nie podpisane blankiety deklaracji zwrócić Tymczasowemu Komitetowi Wykonawczemu, który po zgrupowaniu deklaracji od wszystkich związków prześle wspomniane deklaracje Zarządowi Centralnemu w Piotrogrodzie. Uchwaloną notatkę w tym duchu zamieścić w najbliższym numerze "Biuletynu”.

3. Przyjąć do wiadomości o powołaniu do życia Tymczasowego Komitetu Wykonawczego Wojskowych Polaków w III Syberyjskim Korpusie i o utworzeniu Zarządu Centralnego Związków Wojskowych Polaków 75 Dywizji Piechoty.

4. Polecić Komisji Redakcyjnej ogłosić w najbliższym „Biuletynie” notatkę o zadaniach i celach Towarzystwa Przyjaciół Żołnierza Polskiego' ${ }^{1}$.

5. Następne posiedzenie komitetu zwołać dnia 10 lipca starego stylu o godzinie 8.30 wieczorem.

Prezes podpułkownik Aleksandrowicz

Zastępca prezesa chorąży Czesław Wolff

Sekretarz urzędnik wojskowy Stanisław Zieliński

1 Towarzystwo zostało założone przez osoby cywilne społeczności polskiej zamieszkującej głównie obszary białoruskie. Zajmowało się przede wszystkim organizowaniem pomocy i opieki nad żołnierzami Polakami w armii rosyjskiej i w tworzących się polskich formacjach wojskowych. Odegrało istotną rolę w akcjach związanych z organizowaniem różnych imprez kulturalnych i obchodów narodowych. 


\section{Dokument nr 15}

1917 lipiec 23, Nieśwież. - Protokót nr 15 posiedzenia zwyczajnego Tymczasowego Komitetu Wykonawczego Wojskowych Polaków Rosyjskiej 2 Armii.

Tymczasowy Komitet... postanowił.

1. Zwrócić się do Naczelnego Komitetu Wojskowego w sprawie wytworzenia ściślejszego kontaktu z frontem, mianowania komisarzy przy armiach, ułatwienia w przeniesieniu Polaków na froncie do oddziałów polskich, zajęcia się sprawą polepszenia doli jeńców wojennych Polaków. Jednocześnie postanowiono dać zarys z działalności Tymczasowego Komitetu Wykonawczego w kierunku organizacyjnym.

2. Zwrócić się do związku frontowego o nadesłanie 25 egzemplarzy „Statutu", 200 egzemplarzy „Bracia Żołnierze” i 100 egzemplarzy broszurek Polaków poznańskich; prosić o wysłanie literatury agitacyjnej co najmniej w 300 egzemplarzach; zapytać o adres i cenę „Żołnierza Polskiego" 1.

3. Potwierdzić piśmiennie poczynione ustnie przez dowódcę armii starania o nie wydzielanie Polaków z oddziałów tyłowych do czasu zdecydowania sprawy formacji polskich.

4. W najbliższym „Biuletynie” dać wskazówki co do prowadzenia pracy kulturalno-oświatowej, zamieścić notatkę o polskiej sile zbrojnej, zwrócić się o nadesłanie funduszy na potrzeby Tymczasowego Komitetu Wykonawczego.

Prezes podpułkownik Aleksandrowicz

Zastępca prezesa chorąży Czesław Wolff

Sekretarz urzędnik wojskowy Stanisław Zieliński

1 Chodzi o polską codzienną gazetę wojskową założoną przez chorążego Henryka Bagińskiego, który przed wybuchem pierwszej wojny światowej był w Galicji wybitnym współorganizatorem Polskich Drużyn Strzeleckich, a potem wstąpił do szeregów Legionu Puławskiego, organizowanego w Królestwie Polskim przez ziemianina Witolda Ostoję-Gorczyńskiego. 


\section{Dokument nr 16}

1917 lipiec 26, Nieświez. - Protokót nr 16 posiedzenia zwyczajnego Tymczasowego Komitetu Wykonawczego Wojskowych Polaków Rosyjskiej 2 Armii.

Tymczasowy Komitet... postanowił.

1. Wydrukować i przekazać do Oddziału Sanitarnego, Czerwonego Krzyża, Związku Ziemstw i Miast oraz do zarządów związków dywizyjnych i korpusowych karty rejestracyjne według wzoru nadesłanego przez sekcję sanitarną związku frontowego.

2. Przesłać do związku frontowego spisy oficerów i żołnierzy Polaków pragnących przenieść się do oddziałów polskich.

3. Polecić podpułkownikowi Aleksandrowiczowi i szeregowcowi Donalisowi zbadanie przyczyn dokonanego przez władze aresztowania porucznika Ostrowskiego i pułkownika Nowickiego.

4. Umieścić w „Biuletynie” wskazówki co do prowadzenia kancelarii, zamieścić adres i cenę prenumeraty pism polskich.

Prezes podpułkownik Aleksandrowicz Zastępca prezesa chorąży Czesław Wolff

Sekretarz urzędnik wojskowy Stanisław Zieliński

\section{Dokument nr 17}

1917 lipiec 27, Nieśwież. - Protokót nr 17 posiedzenia nadzwyczajnego Tymczasowego Komitetu Wykonawczego Wojskowych Polaków Rosyjskiej 2 Armii.

Tymczasowy Komitet... postanowił.

W wykonaniu Rozkazu Naczelnego Polskiego Komitetu Wojskowego $\mathrm{Nr} 1$ z dnia 10 lipca starego stylu zwołać na dzień 18 lipca starego stylu w Nieświeżu zjazd przedstawicieli związków dywizyjnych i korpusowych oraz sztabowych dla dokonania wyborów komisarza przy armii i jego zastępcy.

Prezes podpułkownik Aleksandrowicz Zastępca prezesa chorąży Czesław Wolff Sekretarz urzędnik wojskowy Stanisław Zieliński 


\section{Dokument nr 18}

1917 sierpień 5, Nieśwież. - Protokót nr 18 posiedzenia zwyczajnego Zarządu Zwiqzzów Wojskowych Polaków Rosyjskiej 2 Armii.

Zarząd Związków... postanowił.

1. Urządzić dnia 27 lipca starego stylu uroczyste nabożeństwo żałobne za poległych pod Krechowcami ${ }^{1}$ ułanów polskich. Organizację tego zlecić komisji organizacyjnej, do której wybrano: urzędnika wojskowego Zielińskiego, szeregowca Donalisa i starszego podoficera Gawora.

2. Wobec ustąpienia starszego podoficera Krassowskiego w zamian komisji redakcyjnej do redagowania "Biuletynu” upoważnić chorążego Wolffa, który zostaje odpowiedzialnym redaktorem.

3. Zgodzić się na zaproponowany przez Naczelny Komitet Wykonawczy adres telegraficzny: „Sowonoliari 2".

4. Przy jąć do wiadomości sprawozdanie chorążego Wolffa z kroków poczynionych dla spolonizowania jednej z drużyn inżynieryjnych roboczych.

5. Wobec zawiadomienia przez podpułkownika Aleksandrowicza zarządu o wieściach ważnej wagi, otrzymanych od Naczelnego Komitetu Wojskowego z Piotrogrodu, wstrzymać wydanie „Biuletynu” nr 4 do powrotu podpułkownika Aleksandrowicza z Mińska.

6. Propozycję podpułkownika Aleksandrowicza w sprawie zwołania nowego zjazdu omówić po powrocie podpułkownika Aleksandrowicza.

Zastępca prezesa urzędnik wojskowy Stanisław Zieliński Sekretarz chorąży Czesław Wolff

1 Chodzi o bój stoczony w dniu 24 lipca 1917 r. przez Pułk Ułanów Polskich pułkownika Bolesława Mościckiego $\mathrm{z}$ oddziałami niemieckimi należącymi do dywizji generała Karla Litzmanna. Walka rozegrała się na zachodnich przedpolach Stanisławowa i miała na celu powstrzymanie wojsk niemieckich, które usiłowały otoczyć i zniszczyć rosyjską 11 Dywizję Piechoty. Bohaterska postawa ułanów polskich, którzy stawiali opór przez sześć godzin umożliwiła wycofanie zagrożonej dywizji, a następnie wycofał się i pułk polski. Straty poniesione przez pułk Mościckiego były następujące: poległ jeden oficer i 31 szeregowych, rany odniosło 4 oficerów i 46 szeregowych. M. Wrzosek, Polski czyn zbrojny podczas pierwszej wojny światowej 1914-1918, Warszawa 1990, s. $321 \mathrm{i}$. 


\section{Dokument nr 19}

1917 sierpień 10, Nieświez. - Protokót nr 19 posiedzenia zwyczajnego Zarzadu Zwiazków Wojskowych Polaków Rosyjskiej 2 Armii.

Zarząd Związków... postanowił.

1. W wykonaniu zalecenia Zarządu Związków Wojskowych Polaków Frontu Zachodniego z dnia 25 lipca 1917 r. Nr 1084 o obiorze dwóch członków tegoż zarządu od armii 2-giej zwołać na dzień 10 sierpnia starego stylu w gmachu telegrafu sztabowego zebranie przedstawicieli związków dywizyjnych w celu dokonania obioru dwóch kandydatów na stanowiska członków Zarządu Związków Wojskowych Polaków Frontu Zachodniego.

2. Przy jąć do wiadomości o zatwierdzeniu przez Naczelny Polski Komitet Wojskowy na stanowisku komisarza i jego zastępcy przy sztabie armii podkapitana Matuszewskiego ${ }^{1}$ i chorążego Maruszewskiego.

3. Zawiadomić Naczelny Polski Komitet Wojskowy i zarząd związku frontowego o ukonstytuowaniu się stałego Zarządu Związków Wojskowych Polaków Armii 2-giej.

4. O pomoc w sprawie spolonizowania jednej $\mathrm{z}$ drużyn ${ }^{2}$ inżynieryjnych i batalionu ${ }^{3}$... zwrócić się do sztabu I Polskiego Korpusu.

5. Wszcząć starania o odkomenderowanie do biura Zarządu Związków Wojskowych Polaków Armii 2-giej urzędnika wojskowego Stanisława Zielińskiego.

6. Pokryć z funduszy zarządu wydatki na urządzenia nabożeństwa żałobnego dnia 27 lipca za poległych pod Krechowcami ułanów polskich.

7. Wyrazić podziękowanie panom Zielińskiemu, Gaworowi i Donalisowi za trudy poniesione przy organizowaniu nabożeństwa dnia 27 lipca.

Prezes podpułkownik Aleksandrowicz

Zastępca prezesa urzędnik wojskowy Stanisław Zieliński

Sekretarz chorąży Czesław Wolff

1 Chodzi o Ignacego Matuszewskiego, który w dwa lata później był wybitnym oficerem polskiego wywiadu, a w dniu 29 grudnia 1929 r. wszedł w skład gabinetu rządowego Kazimierza Bartla jako minister skarbu.

2 W określeniu drużyna inżynieryjna chodzi o batalion inżynieryjny.

$3 \mathrm{~W}$ punkcie nr 4 po wyrazie batalion w tekście występuje słowo nieczytelne. 


\section{Dokument nr 20}

1917 sierpień 17, Nieświez. - Protokót nr 20 posiedzenia zwyczajnego Zarządu Zwiazków Wojskowych Polaków Rosyjskiej 2 Armii.

Zarząd Związków... postanowił.

1. W wykonaniu rozkazu Naczelnego Polskiego Komitetu Wojskowego z dnia 12 lipca roku bieżącego Nr 23 przesłać temuż Komitetowi 40 rubli, $10 \%$ od wpływów za miesiąc lipiec.

2. Po rozpatrzeniu memoriału Zarządu Centralnego Związków Wojskowych Polaków przy Zarządzie Naczelnika Inżynierów Armii 2-giej z dnia 29 lipca starego stylu nr 7 w sprawie zużytkowania części wpływów otrzymanych od poszczególnych związków dla przesłania do zarządu związku frontowego na potrzeby Zarządu Związków Armii 2-giej i wydawnictwa gazety „Żołnierz Polski” uchwalono następującą rezolucję: „Połowę z wpisowego obrócić na potrzeby Zarządu Związku Wojskowych Polaków Armii 2-giej, drugą zaś połowę wpisowego plus $25 \%$ od składek miesięcznych przesłać związkowi Frontu Zachodniego. Na „Żołnierza Polskiego” zbierać składki dobrowolne".

3. Umieścić w numerze 6-tym „Biuletynu” treść deklaracji, jaką wojskowi Polacy przy wstępowaniu do Polskiej Siły Zbrojnej zobowiązani są podpisać.

4. Zwrócić się do prezesa Komisji Likwidacyjnej do Spraw Królestwa Polskiego ${ }^{1}$ mecenasa Aleksandra Lednickiego z prośbą o zawiadomienie, czy rodziny wojskowych Polaków pozostałe w Królestwie Polskim otrzymuja zapomogi żywnościowe i w jaki sposób żołnierze mogą się zwrócić do państwa o odszkodowanie za zniszczony wskutek działań wojennych w Królestwie Polskim dobytek.

Prezes podpułkownik Aleksandrowicz

Zastępca prezesa urzędnik wojskowy Stanisław Zieliński Sekretarz chorąży Czesław Wolff

1 Komisja Likwidacyjna do Spraw Królestwa Polskiego była organem rosyjskiego Rządu Tymczasowego. Została powołana na podstawie ustawy ogłoszonej 15 marca (starego stylu) 1917 r. w „Wiestniku Wremiennego Prawitielstwa” nr 10. Jako zadanie Komisji określono wyjaśnienie miejsc znajdowania się i stanu majątku państwowych i społecznych instytucji Królestwa Polskiego i określenie sposobu przechowywania i zarządzania nim aż do przekazania go państwu polskiemu, określenie w porozumieniu z odnośnymi urzędami rosyjskimi sposobu likwidacji instytucji państwowych, które były czynne w Królestwie Polskim, wypracowanie projektu wzajemnego ustosunkowa- 
nia Państwa i Kościoła Rzymsko-Katolickiego, wypracowanie przepisów określających położenie jeńców wojennych i cywilnych, poddanych państw nieprzyjacielskich, narodowości polskiej. Publ. M. Wrzosek, Pierwsze sprawozdanie z działalności Komisji Likwidacyjnej do Spraw Królestwa Polskiego, publ. w: Teki Archiwalne, t. VIII, Warszawa 1961, s. 108.

2 Aleksander Lednicki urodził się 2 czerwca 1866 r. w Szejbiczach koło Mińska Litewskiego. Ukończył prawo na Uniwersytecie Moskiewskim i szybko zdobył rozgłos jako znakomity obrońca. W latach 1905-1916 był wybitnym działaczem rosyjskiej partii Konstytucyjno-Demokratycznej. Był w Rosji prezesem różnych polskich organizacji społecznych. Po powrocie do kraju nie odgrywał większej roli w życiu politycznym. Popełnił samobójstwo z przyczyn nie ustalonych w 1934 r.

\section{Dokument nr 21}

1917 sierpien 27, Nieśwież. - Protokót nr 21 posiedzenia zwyczajnego Zarządu Zwiazków Wojskowych Polaków Rosyjskiej 2 Armii.

Zarząd Związków... postanowił.

1. Po rozpatrzeniu listu sekretarza Związku Wojskowych Polaków 9 (nieczytelne słowo) dywizjonu artylerii podjąć starania w celu jak najśpieszniejszego zorganizowania oddziałów korpuśnych IX Korpusu. Jeśli okaże się to niemożliwe, wysłać instruktora.

2. Przeprowadzić ścisłą rejestrację związków wojskowych Polaków armii 2-giej.

3. Umieścić w „Biuletynie” nr 7 adresy instytucji, które ofiarowały pobyt urlopowanym żołnierzom.

4. Udzielić pożyczki w kwocie 100 rubli członkowi Związku Wojskowych Polaków 3 Rejonu Zarządu Naczelnika Inżynierów Armii 2-giej Ryszardowi Zymsowi.

5. Wobec zbyt późnego otrzymania prospektu organu Naczelnego Polskiego Komitetu Wojskowego „Polskich Sił Zbrojnych”, wskutek czego poszczególne związki nie zdołają skomunikować się z redakcją i otrzymać pierwszych numerów pisma, zamówić telegraficznie dla związku 100 egzemplarzy do czasu wyjaśnienia rzeczywistej potrzeby związków.

Prezes podpułkownik Aleksandrowicz

Zastępca prezesa urzędnik wojskowy Stanisław Zieliński Sekretarz chorąży Czesław Wolff 


\section{Dokument nr 22}

1917 wrzesień 7, Nieśwież. - Protokót nr 22 posiedzenia zwyczajnego Zarzqdu Zwiazków Wojskowych Polaków Rosyjskiej 2 Armii.

Zarząd Związków... postanowił.

1. Wobec trudności technicznych związanych $z$ wydawaniem „Biuletynu" w Nieświeżu drukowanie uchwał poszczególnych związków, jak życzył sobie tego Związek Wojskowych Polaków 75 Dywizji Piechoty, w danej chwili nie przedstawia się możebnym.

2. W odpowiedzi na depeszę naczelnika sztabu armii 2-giej z okólnikiem głównodowodzącego wojsk Frontu Zachodniego nr 55985 o stosunku ministra wojny do Naczelnego Polskiego Komitetu i formacji Polskiej Siły Zbrojnej wystosować do Naczelnego Polskiego Komitetu Wojskowego memoriał z żądaniem energicznej obrony interesów żołnierza polskiego; wskazano, aby Naczelny Polski Komitet Wojskowy zażądał stanowczej odpowiedzi od Kiereńskiego i odpowiedź tę zakomunikował.

Prezes podpułkownik Aleksandrowicz

Zastępca prezesa urzędnik wojskowy Stanisław Zieliński Sekretarz chorąży Czesław Wolff

\section{Dokument $\mathrm{nr} 23$}

1917 wrzesien 10, Nieśwież. - Protokót nr 23 posiedzenia zwyczajnego Zarzadu Zwiqzków Wojskowych Polaków Rosyjskiej 2 Armii.

Zarząd Związków... postanowił.

1. Wezwać związki wojskowych Polaków do uroczystego obchodu setnej rocznicy zgonu Tadeusza Kościuszki.

2. Ogłosić w „Biuletynie” rezolucje zebrania Zarządu Centralnego Związku Wojskowych Polaków oddziałów podległych Naczelnikowi Inżynierów Armii 2-giej o stosunku urzędnika 6-tej Inżynieryjnej Roboczej Drużyny Jana Domańskiego do Związku Wojskowych Polaków.

Prezes podpułkownik Aleksandrowicz

Zastępca prezesa urzędnik wojskowy Stanisław Zieliński Sekretarz chorąży Czesław Wolff 


\section{Dokument nr 24}

1917 wrzesień 25, Nieświez. - Protokót nr 24 posiedzenia zwyczajnego Zarządu Zwiazków Wojskowych Polaków Rosyjskiej 2 Armii.

Zarząd Związków... postanowił.

1. Rozszerzyć łamy "Biuletynu” wprowadzając dział z życia związków i drukujacc artykuły aktualne.

2. W związku z protestem wystosowanym przez Naczelny Polski Komitet Wojskowy przeciw rewizji dokonanej w nocy z 30 na 31 sierpnia w lokalu Naczelnego Polskiego Komitetu Wojskowego przez komisję Rady Delegatów Robotniczych i Żołnierskich, $\mathrm{z}$ aresztowaniem przez tak zwany Komitet Siedmiu oficerów polskiego pułku zapasowego w Biełgorodzie, wystosować protesty: do prezesa Rady ministrów, do Centralnego Komitetu Wykonawczego Rad delegatów Robotniczych i Żołnierskich w Piotrogrodzie i do „Komitetu Siedmiu" 1 w Biełgorodzie. W memoriale do prezesa Rady Ministrów domagać się natychmiastowego zalegalizowania Naczelnego Polskiego Komitetu Wojskowego i rozstrzygnięcia sprawy formowania Polskich Sił Zbrojnych zgodnie z uchwałą I Ogólnego Zjazdu Przedstawicieli Wojskowych Polaków w Piotrogrodzie. Tekst protestów opracowany przez urzędnika Zielińskiego został zatwierdzony.

3. Upoważnić urzędnika Zielińskiego i chorążego Wolffa do porozumienia się z przedstawicielami miejscowych instytucji społecznych polskich w celu urządzenia wspólnymi siłami uroczystego obchodu setnej rocznicy zgonu Tadeusza Kościuszki do 2/15 października 1917 r.

4. Nawołać związki wojskowych Polaków do regularnego wnoszenia składek.

5. Biuro Zarządu Związków Wojskowych Polaków Armii 2-giej przeniosło się w dniu 8 września starego stylu z Nieświeża do Słucka.

6. Stwierdzenie nieobecności członków zarządu wachmistrza Gawora i szeregowca Donalisa. Wachmistrz Gawor w ciągu ostatnich kilku tygodni na posiedzenia zarządu nie uczęszcza.

Prezes podpułkownik Aleksandrowicz

Zastępca prezesa urzędnik wojskowy Stanisław Zieliński Sekretarz chorąży Czesław Wolff

1 Chodzi o tak zwaną Rewolucyjną Siódemkę ochrony Rewolucji w Biełgorodzie, powołaną tam po nadejściu wiadomości o zbrojnym wystąpieniu generała Lawra Korniłowa 
(pucz Korniłowa). Na podstawie decyzji tego organu w nocy z 29 n a 30 sierpnia (stary styl) 1917 r. aresztowano dowódcę Zapasowego Pułku Strzelców w Biełgorodzie pułkownika Jakuba Szyszko-Bohusza i siedmiu oficerów, którzy po kilku dniach zostali jednak zwolnieni z aresztu. M. Wrzosek, Przyczynek do historii 1 Rewolucyjnego Putku Polskiego, „Przegląd Historyczny” t. XLVIII, zeszyt 4 z 1957 r., s. 722 i n.

\section{Dokument nr 25}

1917 październik 8, Stuck. - Protokót nr 25 posiedzenia zwyczajnego Zarzqdu Zwiazków Wojskowych Polaków Rosyjskiej 2 Armii.

Zarząd Związków... postanowił.

1. O rezygnacji ze stanowiska członków zarządu wachmistrza Gawora i szeregowca Donalisa zawiadomić w krótkiej notatce w „Biuletynie” nr 13-14, rozpatrzenie zaś motywów rezygnacji i zajęcie względnie umotywowanie tego kroku przez Donalisa i Gawora stanowiska rozpatrzyć na następnym posiedzeniu.

2. Wobec wydzielania przez delegatów Naczelnego Polskiego Komitetu Wojskowego i sztabu I Polskiego Korpusu żołnierzy Polaków do oddziałów I Polskiego Korpusu (delegaci po porozumieniu się ze sztabem armii i zarządem związków wyjechali na front armii 2-giej dnia 16 września), wskutek czego w wielu związkach zostaną zdekompletowane zarządy, wezwać związki do ukonstytuowania prezydiów.

3. Oświetlić w „Biuletynie" hańbiący czyn tych wojskowych Polaków, którzy brali udział w rewizji lokalu Naczelnego Polskiego Komitetu Wojskowego.

4. Poczynić starania w celu zwołania zjazdu Polaków wojskowych frontu.

Zastępca prezesa urzędnik wojskowy Stanisław Zieliński Sekretarz chorąży Czesław Wolff

\section{Dokument nr 26}

1917 październik 25, Stuck. - Protokót nr 26 posiedzenia zwyczajnego Zarzadu Zwiazków Wojskowych Polaków Rosyjskiej 2 Armii.

Zarząd Związków... postanowił.

1. Przyjąć do wiadomości, iż w 7 Dywizji Strzelców Syberyjskich 
i w 7 Dywizji Strzelców Turkiestańskich zarządy dywizyjne jako też poszczególne związki wojskowych Polaków, wobec wyjazdu członków do oddziałów I Polskiego Korpusu, przestały istnieć. Z powodu rozformowania 178 Dywizji Piechoty, której oddziały zostały włączone częściowo do 75 Dywizji, częściowow zaś do 129 Dywizji Piechoty, zarząd centralny wspomnianej dywizji rozwiązał się, a członkowie jego utworzyli Tymczasowy Zarząd Centrali w 129 Dywizji Piechoty, której centrala w osobie członków wstąpiła do I Polskiego Korpusu.

2. Przewidziane statutem Związku Wojskowych Polaków Frontu Zachodniego wpisowe i $25 \%$ od składki członkowskiej polecić przesłać zamiast do związku frontowego, do Zarządu Związku Wojskowych Polaków Armii 2-giej, który z sum wpłaconych przesyłać będzie 10 do Zarządu Związków Wojskowych Polaków Frontu Zachodniego i 10 do Naczelnego Polskiego Komitetu Wojskowego.

3. Wszcząć starania w celu zwołania zjazdu delegatów Polaków wojskowych armii 2-giej na dzień 5 listopada starego stylu.

4. Poczynić starania, aby zainicjowany przez Zarząd Związku Wojskowych Polaków Armii 2-giej zjazd frontowy odbył się dopiero po zjeździe przedstawicieli Polaków wojskowych armii 2-giej.

5. W rozwinięciu oświadczenia złożonego przez delegowanych przez zarząd chorążego Wolffa i sędziego śledczego Maleszewskiego w rozmowie z pełniącym obowiązki komisarza armii 2-giej panem Mojsiejewem podczas bytności delegatów w Nieświeżu w końcu września roku bieżącego, iż ramki kulturalno-oświatowych komisji, podwładnych komitetom ogólnowojskowym, nie mogą zadowolić Polaków wojskowych, którzy jako obywatele wolnego państwa domagać się muszą całkowitego uniezależnienia swych organizacji wojskowych, przesłać komisarzom Rządu Tymczasowego przy armii 2-giej, zgodnie z jego życzeniem memoriał oświetlający pogląd nasz na daną sprawę i wyrażający nasze żądania. Depesza okólnikowa naczelnika sztabu armii 2-giej z dnia 24 września starego stylu nr 1474, w której związki wojskowych Polaków nazwane są kulturalno-oświatowymi organizacjami, zadowolić nas nie może.

Prezes podpułkownik Aleksandrowicz

Zastępca prezesa urzędnik wojskowy Stanisław Zieliński Sekretarz chorąży Czesław Wolff 


\section{Dokument nr 27}

1917 październik 26, Stuck. - Protokót nr 27 posiedzenia zwyczajnego Zarzadu Zwiazków Wojskowych Polaków Rosyjskiej 2 Armii.

Zarząd Związków... postanowił.

1. Wystosować do Centralnego Komitetu Rad Delegatów Robotniczych i Żołnierskich protest przeciwko dwoistej i nieszczerej polityce Centralnego Komitetu RDR i Ż w stosunku do Polaków wyrażający się w tym, że wbrew ciągle i wszędzie proklamowanym przez Centralny Komitet RDRiŻ hasła prawa narodów na „samookreślenie” i uchwale Piotrogrodzkiej RDRiŻ, powziętej w pierwszych dniach po wybuchu rewolucji, w której demokracja rosy jska wy powiedziała się za niepodległością i zjednoczeniem Polski, Centralny Komitet RDRiŻ w nakazie M. I. Skobielewowi, delegowanemu na konferencję Koalicji antyniemieckiej, z warunkiem pokoju Demokracji Rosyjskiej, sprawa Polski ograniczona zos taje do żądania wycofania wojsk niemieckich z granic Rosji, pozostawiając Poznańskie i Galicję pod władzą Austrii i Prus.

2. Kooptować do składu zarządu na miejsce wachmistrza Gawora i szeregowca Donalisa sędziego śledczego Lucjana Maleszewskiego i chorążego Jana Kowalewskiego.

Prezes podpułkownik Aleksandrowicz

Zastępca prezesa urzędnik Stanisław Zieliński Sekretarz chorąży Czesław Wolff

\section{Dokument nr 28}

1917 październik 28, Stuck. - Protokót nr 28 posiedzenia zwyczajnego Zarzadu Zwiazków Wojskowych Polaków Rosyjskiej 2 Armii.

Zarząd Związków... postanowił.

1. Ǔkompletować się w sposób następujący:

prezes podpułkownik Aleksandrowicz,

zastępcy prezesa chorąży Wolff i sędzia Maleszewski

skarbnik chorąży Kowalewski

sekretarz urzędnik wojskowy Zieliński

delegat V Korpusu żołnierz Władysław Cichowski, którego obecność w zarządzie liczyć należy od dnia 1 października starego stylu. 
Pozostałe korpusy nie bacząc na parokrotne wezwania zarządu wyborów swych przedstawicieli do zarządu dotychczas nie dokonały.

2. Po przeczytaniu listów byłych członków zarządu Gawora i Donalisa ze zrzeczeniem się stanowiska członków zarządu skonsta tować, co następuje:

a) w umotywowaniu zrzeczenia się mandatu przez wachmistrza Gawora podkreślić kłamliwość zawartych w nim następujących dowodzeń:

- „jako skarbnik nie był zawiadomiony o przyjęciu kasy"; kilkakrotnie chorąży Wolff proponował wachmistrzowi Gaworowi przyjąć kasę, od czego ten ostatni wciąż się jednak wymawiał;

- „prócz dwóch razy nigdy nie był zawiadamiany o posiedzeniach”; na równi $z$ innymi członkami był zawiadamiany przeważnie telefonicznie pod wskazanym przez siebie numerem, lecz nie uczęszczał (w Słucku o posiedzeniu z 25 września zawiadomił go osobiście chorąży Wolff wskazując lokal zarządu);

- „zarząd w „Biuletynie” wyraża wolę wszystkich Polaków armii, czego nie ma prawa czynić, ponieważ dużo Polaków łączy się poglądami z Komitetem Głównym (lewicy)"; zjazd delegatów Polaków wojskowych w dniu 18/31 lipca uznał Naczelny Polski Komitet Wojskowy jako przedstawiciela wszystkich Polaków wojskowych i nikt z obecnych na zjeździe w tej liczbie pan Gawor nie zawiadomił o przynależności do tak zwanego Komitetu Głównego.

b) szeregowiec Donalis motywuje swoje ustąpienie niepołączniem się Naczelnego Komitetu Wojskowego z „Komitetem Głównym”, którego jest zwolennikiem; zarząd uznaje lojalność postępku pana Donalisa, stwierdza jednak, że o przynależności swej do „Komitetu Głównego” pan Donalis winien był powiadomić wyborców zjazdu w dniu 18 lipca, kiedy dokonywane były wybory.

O motywach ustąpienia panów Donalisa i Gawora zarząd zdecydował zawiadomić najbliższy zjazd delegatów Polaków wojskowych armii 2-giej podając do wiadomości zjazdu zapatrywania na tę sprawę.

3. O mówiwszy depesze Naczelnego Polskiego Komitetu Wojskowego do zarządu związków nr 892 i do podpułkownika Aleksandrowicza nr 909, wydelegować na konferencję, która ma się odbyć dnia 27 października w Piotrogrodzie chorążego Wolffa jako przedstawiciela zarządu i podpułkownika Aleksandrowicza jako zastępcę Głównego Polskiego Wojskowego Komitetu Wykonawczego przy armii 2-giej, dając im następującą instrukcję w sprawach, które mają być poruszone na zjeździe.

a) Kwestia stanowiska wojskowych Polaków w sprawie wyborów do konstytuanty. 
Podtrzymać opinię wygłoszoną na zebraniu przedstawicieli związków dywizyjnych $z$ dnia 10 sierpnia starego stylu, że Polacy, mieszkańcy Królestwa Polskiego, w wyborach do konstytuanty rosyjskiej udziału przyjmować nie powinni.

b) Kwestia Organizacji przedstawicielstwa Głównego Polskiego Wojskowego Komitetu Wykonawczego przy frontach, armiach i okręgach.

Poprzeć projekt przyjęty na posiedzeniu informacyjnym w Mińsku dnia 4 października, aby przedstawiciele Głównego Polskiego Wojskowego Komitetu Wykonawczego byli przeniesieni do polskiego korpusu, stamtąd odkomenderowani do Naczelnego Polskiego Komitetu Wojskowego i z ramienia tego ostatniego wysłani do miejscowej działalności.

c) Kwestia reorganizacji podstaw związków wojskowych Polaków i istnienie takowych w Polskiej Sile Zbrojnej.

Punkt o reorganizacji związków wojskowych Polaków jest niezrozumiały. Co zaś do istnienia związków w Polskiej Sile Zbrojnej, rozstrzygnąć tę sprawę można by w sposób następujący: każdego oficera i żołnierza Polaka znajdującego się na służbie w oddziałach Polskiej Siły Zbrojnej uważać za członka związku Wojskowych Polaków Frontu Zachodniego z prawem korzystania ze środków kulturalno-oświatowych związku i udziału w konstytuowaniu władz zarządu związku.

Wniosek, aby przedstawiciele Głównego Polskiego Wojskowego Komitetu Wykonawczego przy dywizjach polskich byli zarazem łącznikiem kulturalno-oświatowym między Związkiem Wojskowych Polaków Frontu Zachodniego i Polską Siłą Zbrojną należy popierać.

W nowym statucie związków wojskowych Polaków pominięta jest sprawa organizacji oddziałów podległych wydziałom sztabu armii.

d) Kwestia zasadniczego stanowiska wojskowych Polaków do przedstawicielstwa narodowościowego w komitetach armii rosyjskiej.

Związki armii muszą każdorazowo rozstrzygnąć sprawę tworzenia bloku z poszczególnymi komitetami narodowościowymi, stałe zaś zawarcie przymierza jest niewskazane.

e) Kwestia legalizacji związków wojskowych Polaków w armii rosyj-. skiej.

$\mathrm{Na}$ warunki określone dla wszystkich innych narodowości, a wyrażające się w istnieniu kulturalno-oświatowych komisji, podległych ogólnym komitetom wojskowym, zgodzić się nie możemy. Jako obywatele państwa uznanego za niepodległe, mający odmienne zadania niż komitety rosyjskie, musimy domagać się całkowitej samodzielności działania dla naszych związków oraz zwolnienia prezydium od za jęć służbowych. 
f) Kwestia Stanowiska Naczelnego Polskiego Komitetu Wojskowego do ugrupowań politycznych.

Naczelny Polski Komitet Wojskowy, zgodnie z dotychczasowym stanowiskiem, powinien stać ponad wszelkimi partiami, utrzymując kontakt z tymi, które popierają zadania i cele Polaków wojskowych.

g) Sprawa taktyki w postępowaniu do Rządu Tymczasowego.

Z początkiem wybuchu rewolucji rosyjskiej do chwili obecnej Polacy wojskowi popierają Rząd Tymczasowy dążąc do podtrzymania ładu i karności w szeregach wojskowych. Wobec jednak stanowiska, jakie rząd ten zajmuje w stosunku do nas wojskowych Polaków, odmawiając legalizacji Naczelnego Polskiego Komitetu Wojskowego i związków, rozwiązania sprawy formowania Polskiej Siły Zbrojnej zgodnie z uchwałą I Ogólnego Zjazdu Polaków Wojskowych w Piotrogrodzie, nie bacząc na to, że Ukraińcy, którym nie przyznano wszak prawa do niepodległości, uzyskali znów zezwolenie na zukrainizowanie piętnastu dywizji i prześladowanie jeńców Poalków, co wyraża się w cofnięciu nadanych 30 czerwca ulg i traktowania Polaków nie jak jeńców pozostałych narodowości słowiańskich, a na równi z Niemcami i Madziarami, Polacy wojskowi, w wypadku jeśli rząd nie zmieni swego postępowania, winni wykorzystać całkowicie swe prawa wypływające z tytułu obywateli państwa niepodległego, aż do wystąpienia $z$ szeregów armii rosyjskiej włącznie.

h) Stosunek do Rady Delegatów Robotniczych i Żołnierskich.

I Ogólny Zjazd Delegatów Polaków Wojskowych zwrócił się z braterskim pozdrowieniem do Demokracji Rosyjskiej dając tym wyraz uznania za inicjowanie przez Piotrogrodzką Radę Delegatów Robotniczych i Żołnierskich ogłoszenia prawa narodu polskiego do niepodległości i zjednoczenia, późniejszy jednak stosunek rewolucyjnej demokracji rosyjskiej, wyrażający się w gwałcie nad Naczelnym Polskim Komitetem Wojskowym i chęci ograniczenia granic Polski („nakaz” M. I. Skobielewowi) tylko do byłego zaboru rosyjskiego zepsuł wrażenie wywarte przez pierwszą deklarację. Nie wchodząc w ocenę stosunku Rady Deputatów Robotniczych i Żołnierskich do Polaków, organizację tę uważamy za instytucję prywatną.

i) Sprawa taktyki w postępowaniu do państw Koalicyjnych.

Uznając, że tylko zwycięstwo mocarstw Koalicji może dać nam rozwiązanie sprawy polskiej w duchu niepodległości i połącznenia wszystkich trzech zaborów w jedną całość, stwierdzić musimy, że rezerwa tych mocarstw w sprawie Polski i nie reagowanie na akty niemieckie dające Polsce pewną dozę samodzielności wewnętrznej, wywierają na Polaków przygniatające wrażenia. Czas już zażądać, aby mocarstwa Koalicji uroczystym aktem 
rządów stwierdziły prawo Polski do niepodległości i zjednoczenia i zamieściły w szeregu zasadniczych celów wojny postulat rozwiązania sprawy państwa polskiego w duchu naszych żądań.

j) Sprawa zwołania II Ogólnego Zjazdu Delegatów Polaków Wojskowych.

Zwołanie zjazdu uznać za nadzwyczaj pożądane, przy czym wszyscy przyjmujący w nim udział muszą podporządkować się woli większości.

4. Podczas wyjazdu chorążego Wolffa do Moskwy i Piotrogrodu redagowanie „Biuletynu” zlecić chorążemu Janowi Kowalewskiemu.

Prezes podpułkownik Aleksandrowicz Zastępca prezesa chorąży Czesław Wolff Sekretarz urzędnik Stanisław Zieliński

\section{Dokument nr 29}

1917 listopad 15, Stuck. - Protokót nr 29 posiedzenia zwyczajnego Zarządu Zwiazków Wojskowych Polaków Rosyjskiej 2 Armii.

Zarząd Związków... postanowił.

1. Wobec trudności zwołania zjazdu w Nieświeżu, który przepełniony jest delegatami rosyjskich organizacji wojskowych $\mathrm{w}$ związku $\mathrm{z}$ ostatnim przewrotem politycznym, projektowany na 8 listopada II Zjazd Delegatów Polaków Wojskowych Armii 2-giej zwołać na dzień 15 listopada do Słucka. $\mathrm{O}$ zjeździe zawiadomić związki telegraficznie.

2. Podzielając pogląd Naczelnego Polskiego Komitetu Wojskowego, iż Polacy uważający się za obywateli Królestwa Polskiego, udziału w wyborach do konstytuanty rosyjskiej przyjmować nie powinni, niezależnie od rozesłanych o tym zawiadomieniach, zamieszczony będzie stosowny komunikat w najbliższym „Biuletynie”.

3. Opracowanie ostateczne programu II Zjazdu Wojskowych Polaków Armii 2-giej odłożyć do przyjazdu chorążego Wolffa z konferencji delegatów armii i okręgów w Piotrogrodzie.

Prezes podpułkownik Aleksandrowicz Sekretarz urzędnik Stanisław Zieliński 


\section{Dokument nr 30}

1917 listopad 18, Stuck. - Protokót nr 30 posiedzenia zwyczajnego Zarzadu Związków Wojskowych Polaków Rosyjskiej 2 Armii.

\section{Zarząd Związków... postanowił.}

1. Wysłuchawszy sprawozdania chorążego Wolffa o przebiegu obrad konferencji delegatów armii i okręgów w Piotrogrodzie w dniach 24-31 października ${ }^{1}$ z udziałem członków Naczelnego Polskiego Komitetu Wojskowego, wobec ważności sparw omawianych na konferencji, zwołać ma dzień 12 listopada w Słucku walne zgromadzenie Polaków słuckiego garnizonu dla zaznajomienia ich $\mathrm{z}$ bieżącym momentem politycznym i reakcjami konferencji.

2. Odezwę Naczelnego Polskiego Komitetu Wojskowego do Polaków wojskowych $z$ wezwaniem do powstrzymania się od udziału w walkach politycznych w Rosji wydrukować w 500 egzemplarzach, rozkleić w miastach i na stacjach w rejonie armii 2-giej oraz przesłać do zarządów związków. Niezależnie od tego wezwanie powyższe wydrukować w najbliższym „Biuletynie".

3. W programie obrad II Zjazdu Delegatów Wojskowych Polaków Armii 2-giej umieścić:

a) Sprawozdanie Zarządu Związku Wojskowych Polaków Armii 2-giej.

b) Sprawozdanie chorążego Wolffa o konferencji w Piotrogrodzie.

c) Sprawozdanie delegatów armii 2-giej w Zarządzie Związku Wojskowych Polaków Frontu Zachodniego podkapitana Lipczyńskiego i podoficera Zendlewicza.

d) Rozpatrzenie statutu opracowanego przez Zarząd Centralny Związków Wojskowych Polaków.

e) Komunikat o położeniu spraw polskich w kraju i na emigracji.

f) Sprawa formowania Polskiej Siły Zbrojnej.

g) Obrona interesów polskich w kraju i na emigracji.

h) Kwestia demobilizacji i powrotu do kraju.

i) Sprawa zapomóg rodzinom żołnierzy, które pozostały w Królestwie Polskim i korespondencji z krajem.

j) Dyrektywa dla delegatów na zjazd przedstawicieli Polaków wojskowych Frontu Zachodniego.

k) Wybory delegatów na zjazd frontowy.

l) Wybory członków Zarządu Związków Wojskowych Polaków armii 2-giej. 
ł) Wolne wnioski.

\author{
Prezes podpułkownik Aleksandrowicz \\ Zastępca prezesa chorąży Czesław Wolff \\ Sekretarz urzędnik Stanisław Zieliński
}

1 Chodzi o spotkanie mające na celu opracowanie planu mobilizacji ochotników do służby w polskich formacjach wojskowych. W wyniku narad postanowiono powołać Komisję Mobilizacyjną złożoną z przedstawicieli Naczelnego Polskiego Komitetu Wojskowego oraz delegatów reprezentujących terenowe związki wojskowych Polaków. Jako przedstawiciele Naczelnego Polskiego Komitetu Wojskowego w skład powołanej komisji weszli: podporucznik Adam Piotrowski, chorąży Zygmunt Borawski i chorąży Władysław Kiedrzyński, a delegatów reprezentowali w komisji kapitan Ignacy Matuszewski, chorąży Czesław Wolff i podporucznik Tadeusz Jurkowski. M. Wrzosek, Polskie korpusy..., s. 107 .

\title{
Dokument nr 31
}

1917 grudzień 3, Stuck. - Protokót nr 31 posiedzenia zwyczajnego Zarzqdu Zwiazków Wojskowych Polaków Rosyjskiej 2 Armii.

Zarząd Związków... postanowił.

1. Wobec wyjazdu w dniu 24 listopada członków zarządu i obranego na zjeździe prezesa pułkownika Szpręglewskiego, zastępcy prezesa chorążego Wolffa, sekretarza urzędnika Zielińskiego i członka żołnierza Cichowicza na zjazd frontowy, kierownictwo biura zarządu na czas nieobecności wspomnianych członków powierzyć zastępcy prezesa sędziemu Maleszewskiemu.

2. Niezależnie od rozesłania sprawozdania i uchwał zjazdu do związków i redakcji gazet polskich, uchwałę zjazdu o opuszczeniu szeregów armii rosyjskiej wydrukować w 500 egzemplarzach i rozpowszechnić wśród wojskowych Polaków armii 2-giej.

3. Ǔważając, że podziału między pracą związku i funkcjami przedstawiciela Głównego Polskiego Wojskowego Komitetu Wykonawczego przy armii przeprowadzać nie należy, że podział taki mógłby tylko szkodliwie odbić się tak na pracy związku, jak i na sprawie wydzielania Polaków do Polskiej Siły Zbrojnej, pracować nadal wspólnie $z$ byłym prezesem podpułkownikiem Aleksandrowiczem, który zastosowu jąc się do życzeń Naczelnego Polskiego Komitetu Wojskowego, aby jego przedstawiciele nie byli prezesami związków, 
wystawioną przez zjazd kandydaturę swoją na prezesa cofnął. Jednocześnie zarząd wyraził pogląd, że podział funkcji, wystawiony przez Naczelny Polski Komitet Wojskowy, może być tylko warunkiem formy, a w praktyce zastosować się nie da.

Zastępca prezesa chorąży Czesław Wolff Sekretarz urzędnik Stanisław Zieliński

\section{Dokument nr 32}

1917 grudzień 20, Stuck. - Protokót nr 32 posiedzenia zwyczajnego Zarządu Zwiazków Wojskowych Polaków Rosyjskiej 2 Armii.

Zarząd Związków... postanowił.

1. Wobec tego, że $z$ braku obsługi bataliony obozowe są stopniowo likwidowane, konie $\mathrm{w}$ batalionach obozowych ${ }^{1}$ bez doglądu giną $\mathrm{i}$ są bądź sprzedawane, bądź też odsyłane do zạpasów końskich w tyłach, wydelegować pułkownika Szpręglewskiego ${ }^{2}$ i podpułkownika Aleksandrowicza do naczelnika sztabu armii 2-giej w celu uzyskania pozwolenia na spolonizowanie jednego $z$ batalionów obecnych, ewentualnie o przebadanie koni i majątku likwidowanych batalionów obozowych do polskiego korpusu.

2. Poczynić starania o sporządzenie we wszystkich oddziałach i zarządach armii drogą urzędową spisów wojskowych Polaków i przesłaniu tych spisów, po zgrupowaniu w sztabie armii do zarządu związków.

3. Na wniosek zarządu dywizyjnego Związku Wojskowych Polaków Naczelnika Inżynierów Armii 2-giej rozpatrzono list urzędnika 61 inżynieryjnej drużyny Jana Domańskiego i postanowiono skruchę z powodu jego nieobywatelskiego niegodnego Polaka postępku uznać za szczerą, zwrócić mu honor Polaka i żołnierza i polecić Związkowi Wojskowych Polaków 61 drużyny przyjąć do liczby członków.

4. Wobec objęcia przez sekretarza związku urzędnika Zielińskiego mandatu członka Zarządu Związku Wojskowych Polaków Frontu Zachodniego, powierzyć sekretariat chorążemu Wolffowi. Jednocześnie wobec zdekompletowania zarządu przez równoczesne ustąpienie ze składu jego skarbnika wolontariusza Matuszewskiego, obranego zastępcą członka zarządu Związku Wojskowych Polaków Frontu Zachodniego i członka żołnierza Cichowicza, 
zwolnionego od służby wojskowej, postanowiono na miejsce ustępujących kooptować nowych członków.

Prezes zarządu pułkownik Szpręglewski

Przedstawiciel GPWKW podpułkownik Aleksandrowicz Sekretarz urzędnik Stanisław Zieliński

1 Słowo obozowy jest rusycyzmem, winno być taborowy.

2 Chodzi o pułkownika Eugeniusza Szpręglewskiego, który potem był szefem sztabu w I Korpusie Polskim generała Józefa Dowbor-Muśnickiego.

\section{Dokument nr 33}

1917 grudzień 22, Stuck. - Protokót nr 33 posiedzenia nadzwyczajnego Zarządu Zwiazków Wojskowych Polaków Rosyjskiej 2 Armii.

Zarząd Związków... postanowił.

1. Rozpatrzywszy depeszę gławkowiercha ${ }^{1}$ Krylenki nr 8728 wtrącająca się do spraw wewnętrznych polskich, wstrzymującą dalsze formowanie Polskiej Siły Zbrojnej i zakazującą zwoływania zjazdów narodowościowych, wystosować telegraficzny protest piętnujący Krylenkę. Kopie protestu rozesłać do wszystkich związków armii i okręgów, Naczelnego Polskiego Komitetu Wojskowego, Komisji Likwidacyjnej do Spraw Królestwa Polskiego i Rady Komisarzy Ludowych.

2. Nie zważać na rozkaz Krylenki i w dalszym ciągu prowadzić rozpoczętą pracę wydzielając Polaków drogą rewolucyjną.

3. Wobec bezsilności władz, wskutek której naczelnik sztabu armii nic w sprawie spolonizowania batalionu obozowego i otrzymania koni pomóc nam nie może, zwołać na 22 grudnia przedstawicieli Polaków od każdego transportu dla omówienia środków dla dopięcia celu.

Prezes zarządu pułkownik Szpręglewski

Przedstawiciel GPWKW podpułkownik Aleksandrowicz

Sekretarz urzędnik Stanisław Zieliński

1 Gławkowierch to rosyjski skrót odpowiadający słowu głównodowodzący; po obaleniu rosyjskiego Rządu Tymczasowego funkcję tę sprawował chorąży Mikołaj Krylenko. 


\section{Dokument nr 34}

1918 styczeń 1, Stuck. - Protokót nr 34 posiedzenia zuyczajnego Zarzqdu Zwiazków Wojskowych Polaków Rosyjskiej 2 Armii.

Zarząd Związków... postanowił.

1. Po wysłuchaniu sprawozdania pułkownika Szpręglewskiego z posiedzenia Centralnego Komitetu Obywatelskiego w sprawie powrotu do kraju wygnańców dać pełnomocnictwo do stałego bywania na posiedzeniach Centralnego Komitetu Obywatelskiego w charakterze przedstawiciela Związku Wojskowych Polaków Armii 2-giej.

2. Zakomunikować Naczelnemu Polskiemu Komitetowi Wojskowemu o gwałtach i grabieżach polskich majątków w okolicach Klecka Polaka porucznika Woyniłowicza, nr 12221.

3. Ogłosić w „Biuletynie” o powstałej w Bobrujsku kooperatywie wojskowych Polaków zorganizowanej przez Związek Wojskowych Polaków przy Oddziale Gospodarczym Zarządu Naczelnika Inżynierów Armii 2-giej.

4. Zaliczyć Aleksandra Tarasiewicza do pułku inżynieryjnego jako wolontariusza $z$ odkomenderowaniem do Związku Wojskowych Polaków Armii 2-giej w charakterze ordynansa. Tarasiewiczowi do czasu zaliczenia do szeregu płacić diety po 3 ruble dziennie, zaś po zaliczeniu po 1 rublu dziennie.

5. Przyjąć w charakterze biuralisty p. (nazwisko nieczytelne) i płacić po 66 rubli miesięcznie.

6. Biuralistce pani Walerii Mieszkowskiej podwyższyć płace poczynając od miesiąca grudnia do 100 rubli miesięcznie.

Prezes zarządu pułkownik Aleksandrowicz

Przedstawiciel GPWKW podpułkownik (brak nazwiska)

Sekretarz chorąży Czesław Wolff 


\section{Dokument nr 35}

1918 styczeń 4, Stuck. - Protokót nr 35 posiedzenia Zarzadu Zwiazków Wojskowych Polaków Rosyjskiej 2 Armii z udziatem przedstawicieli transportów wojskowych.

(Nazwy jednostek wojskowych z podaniem liczby służących Polaków i nazwiska przedstawicieli):

2 Batalion 6 transport Ignacy Mrowiński

2 batalion 2 transport Antoni Kmieciak

(10 Polaków)

4 batalion 18 transport Adam Stanik

11 batalion 55 transport Romuald Mączyński

$(34-"-)$

$(70-"-)$

52 obozowy batalion 256 transport Andrzej Kierzkowski

$(6-\cdots-)$

52 obozowy batalion 256 transport Konstanty Skibiński

$(70-"-)$

52 obozowy batalion 257 transport Wincenty Tymiński

52 obozowy batalion 258 transport Adam Przydatek

52 obozowy batalion 258 transport Stanisław Radzikowski

52 obozowy batalion 259 transport Władysław Dybowski $\quad(70-"-)$

2 armijnej artyleryjskiej naprawczej majstrowni Józef Szoplik (24 — - ) oraz dwóch przedstawicieli Związku Wojskowych Polaków sztabu armii (lewicy)!

1. Po oświetleniu sprawy spolonizowania transportów i odbywającej się ich częściowej demobilizacji przyjęto jednogłośnie następu jącą uchwałę: "Transportów formowanych w Polsce nie rozformowywać, a cały majątek zostawić w rękach żołnierzy Polaków dla powrotu do kraju ludzi wraz z inwentarzem i całym majątkiem w celu oddania ludności tych okolic, gdzie te transporty były formowane".

2. Stwierdzono, że w Polsce formowane były następujące obozowe bataliony z 5-ciu transportów każdy: 52-gi w Siedlcach, 2-gi w Bielsku ${ }^{1}, 4$-ty w Kobryniu.

3. Dla wykonania powyższej uchwały postanowiono powołać komisję złożoną z przedstawicieli po jednym od każdego obozowego batalionu. Przedstawiciele będą przysyłani na miejsce.

Prezes pułkownik -

Przedstawiciel NPKW Aleksandrowicz

Sekretarz chorąży Czesław Wolff

1 Chodzi o Bielsk Podlaski. 


\section{Dokument nr 36}

1918 styczeń 10, Stuck. - Protokót nr 36 posiedzenia Zarzqdu Zwiqzków Wojskowych Polaków Rosyjskiej 2 Armii.

Zarząd postanowił.

1. Zapisać do protokółu, że w dniu 27 grudnia, z powodu wysłanej do zwierzchniego głównodowodzącego Krylenki za numerem 1331 depeszy, zostali zaaresztowani z rozporządzenia tegoż Krylenki przez Komitet Rewolucyjny Armii 2-giej przedstawiciel Naczelnego Polskiego Komitetu Wojskowego przy Armii 2-giej podpułkownik Aleksandrowicz i prezes Zarządu Związków Wojskowych Polaków Armii 2-giej pułkownik Szpręglewski. Aresztowani zostali wysłani do Mińska.

2. Do czasu wyjaśnienia sytuacji i otrzymania wiadomości od zarządu związku frontowego wstrzymać się z jakąkolwiek akcją, jak również nie wysyłać depeszy do Krylenki w tej sprawie ograniczając się zwróceniem się do zarządu związku Frontu Zachodniego o pomoc.

3. Uznano za konieczne zwołanie w najbliższym czasie oficjalnego zjazdu wojskowych Polaków armii 2-giej, ażeby całą powagą zjazdu zareagować na areszty po całkowitym już wyjaśnieniu sytuacji.

Zastępca prezesa Maleszewski

Sekretarz chorąży Czesław Wolff

\section{Dokument nr 37}

1918 styczeń 16, Stuck. - Protokót nr 37 posiedzenia zwyczajnego Zarzadu Zwiqzków Wojskowych Polaków Rosyjskiej 2 Armii.

Zarząd postanowił.

1. Powołać komisję zjazdową składającą się z pięciu członków. W skład komisji weszli: chorąży Wolff, sędzia Maleszewski, K. Gawor, K. Ploch i jeden przedstawiciel Związku Wojskowych Polaków XV Inżynieryjnej Brygady.

2. Zjednoczeniu Międzypartyjnemu w sprawie werbunku oficerów i żołnierzy Polaków do armii francuskiej odpowiedzieć, że w tej sprawie spełniamy rozporządzenia Naczelnego Polskiego Komitetu Wojskowego. 
3. Dla zasilenia kasy zarządu postanowiono urządzić wieczór teatralny, zwrócić się o subsydium do Związku Ziemian Ziemi Słuckiej oraz poprosić o zapomogę Naczelny Polski Komitet Wojskowy.

4. Przy jąć do wiadomości, że delegacja międzyfrontowa zwołuje II Powszechny Zjazd Wojskowych Polaków na dzień 20 lutego. Zapoznać się $z$ ordynacją wyborczą w celu przeprowadzenia wyborów na II Zjeździe Armii 2-giej.

5. Przyjąć do wiadomości, że Związek Wojskowych Polaków Sztabu 2 Armii (lewicy) wydelegował na stałego członka zarządu jako swego przedstawiciela kolegę Krassowskiego.

Zastępca prezesa L. Maleszewski Sekretarz chorąży Czesław Wolff

\section{Dokument nr 38}

1918 styczeń 21, Stuck. - Protokót nr 38 posiedzenia zwyczajnego Zarzqdu Zwiazków Wojskowych Polaków Rosyjskiej 2 Armii.

Zarząd postanowił.

1. Wobec konieczności wysłania delegata do Kijowa na konferencję zwołaną w dniu 16 stycznia (starego stylu) przez prezesa Naczelnego Polskiego Komitetu Wojskowego chorążego Raczkiewicza porozumieć się uprzednio z chorążym Mikulicz-Radeckim i jego władzą co do możliwości wydelegowania go ze względów służbowych.

2. Przyjąć do wiadomości, że komisja zjazdowa ukonstytuowawszy się pod przewodnictwem chorążego Wolffa naznaczyła dzień zjazdu na 15 stycznia (starego stylu) i wezwania na zjazd w stosunku 1 do 50-ciu Polaków i 2-ch powyżej 50-ciu Polaków, postanowiła rozesłać drogą służbową, a prócz tego wydać odpowiednie odezwy.

3. Na zapytanie zarządu Związku Wojskowych Polaków Frontu Zachodniego o sposobie korespondencji z krajem przez kordon niemiecki odpowiedzieć, że korespondencję taką w rejonie armii 2-giej zorganizował Związek Wojskowych Polaków Sztabu Armii 2-giej (lewica) dzięki czemu można przesyłać listy do kraju za opłatą na koszty przesyłki 50 kopiejek od listu.

4. Porozumieć się $\mathrm{z}$ oddziałami sztabu armii w sprawie przyjmowania na służbę $\mathrm{z}$ wolnego najmu żołnierzy zwolnionych $\mathrm{z}$ wojska na zasadzie rozkazu gławkozapa nr 49/2353-52. 
5. W miarę możliwości ogłosić w „Biuletynie” rezolucję Związku Wojskowych Polaków (lewicy) w sprawie zajścia z Centralnym Komitetem Obywatelskim.

Zastępca prezesa L. Maleszewski Sekretarz chorąży Czesław Wolff

\section{Dokument nr 39}

1918 luty 2, Stuck. - Protokót nr 39 posiedzenia nadzwyczajnego (nagłego) Zarzqdu Zwiqzków Wojskowych Polaków Rosyjskiej 2 Armii.

Zarząd postanowił.

Wobec spodziewanych starć wojsk Polskiej Siły Zbrojnej z wojskami rosyjskimi w celu zapobieżenia przelewowi krwi zwrócić się do dowódcy armii i komitetu rewolucyjnego armii 2-giej z propozycją wysłania do Bobrujska delegacji polsko-rosyjskiej, która by po zbadaniu bezstronnym sprawy wpłynęła na złagodzenie zaostrzonych stosunków między wojskami, czym uchroniła by i ludność cywilną polską od możliwych gwałtów.

Zastępca prezesa L. Maleszewski Sekretarz chorąży Czesław Wolff

\section{Opracowanie}

1918 czerwiec 24. - Historia Zarzqdu Zwiazków Wojskowych Polaków Rosyjskiej 2 Armii.

Teczki z papierami, dzienniki, czasopisma złożone w niedużej skrzyni - oto cała spuścizna pozostała z likwidacji Zarządu Związków Wojskowych Polaków Armii 2-giej. Przeglądając te na pozór martwe szpargały widać jak w kalejdoskopie przesuwające się kolejno: powstanie, rozwój i działalność Zarządu Wojskowych Polaków Armii 2-giej w osobach przedstawicieli jego, ludzi dobrej woli, energii i zapału.

Po zrzuceniu jarzma caratu Polacy wojskowi rozproszeni na olbrzymich obszarach frontów i tyłów Rosji, jako synowie narodu, który nigdy duchem nie przestał być wolnym, poczuli instynktowną potrzebę zrzeszania się i łą- 
czenia, aby skoordynowanym wysiłkiem wytworzyć organizację mającą przynieść pożytek krajowi.

Praca w kierunku wytworzenia organizacji Związku Wojskowych Polaków w Armii 2-giej datuje się od początku kwietnia 1917 roku. Oddziały sztabu armii 2-giej, zgrupowane w Nieświeżu, w dniu 5 (18) kwietnia 1917 roku zwołały na podstawie ogłoszenia przez Rząd Tymczasowy rosyjski niepodległości Polski ${ }^{1}$ ogólne zebranie wojskowych Polaków załogi nieświeskiej, na którym, po szczegółowym rozpatrzeniu bieżącego momentu uchwalono tworzyć związki wojskowych Polaków i utworzywszy na całym obszarze Rosji sieć związków powołać naczelną organizację i przystąpić do wydzielania Polaków z armii rosyjskiej w celu stworzenia armii polskiej.

Upoważnieni przez ogólne zebranie (podrotmistrz Miniszewski², chorążowie Wolff ${ }^{3}$ i Szymański ${ }^{4}$, urzędnik wojskowy Zieliński ${ }^{5}$, starszy podoficer Gawor, młodszy podoficer Ryszard Krajewski i szeregowiec Józef Krycz) wydali odezwę streszczającą uchwały zebrania. Był to impuls samoistny, pod wpływem wyczuwania potrzeby czynu dla dobra Matki Ojczyzny, dla której żołnierz odziany w szary szynel rosyjski nie zatracił miłości.

To pierwsze zebranie założyło podwaliny pod przyszłą organizację naczelną, Zarząd Związków Wojskowych Polaków Armii 2-giej, w którego historii głównymi etapami normującymi działalność były zjazdy, a mianowicie pięć zjazdów delegatów wojskowych Polaków armii 2-giej:

a) pierwszy 21 maja (3 czerwca) 1917 r. w Nieświeżu,

b) drugi 18 (31) lipca 1917 r. w Nieświeżu,

c) trzeci 10 (23) sierpnia 1917 r. w Nieświeżu,

d) czwarty 15 (28) listopada 1917 r. w Słucku,

e) piąty 15 (28) stycznia 1918 r. w Słucku;

dwa zjazdy przedstawicieli wojskowych Polaków Frontu Zachodniego:

a) pierwszy 16-21 kwietnia 1917 r. w Mińsku,

b) drugi 26 listopada-2 grudnia 1917 r. w Mińsku.

Ponadto I Ogólny Zjazd Wojskowych Polaków w Piotrogrodzie dnia 6 (19 czerwca) 1917 r. oraz Konferencja w Piotrogrodzie od dnia 24 do 31 października (starego stylu) 1917 r. Posiedzeń Zarząd Związków Wojskowych Polaków Armii 2-giej odbył 39.

W dniu 10 (23) kwietnia 1917 r. w Nieświeżu, w lokalu klubu oficerskiego Zarządu Jenerała Kwatermistrza ${ }^{6}$, odbyło się zebranie wyborcze Polaków zaproszonych $\mathrm{z}$ oddziałów sztabu i z oddziałów wojskowych oraz organizacji podlegających bezpośrednio sztabowi 2 armii dla dokonania wyboru delegatów na frontowy zjazd wojskowych Polaków, mający się odbyć dnia 16 (29) kwietnia w Mińsku Litewskim. 
Zwołanie i organizacja tego zebrania powierzone zostały podpułkownikowi Aleksandrowiczowi ${ }^{7}$, którego przez aklamację obrano na przewodniczącego. Na zastępcę powołano chorążego Szymańskiego, na sekretarza Zielińskiego, na asesorów podoficera $z$ kompanii sztabu armii 2-giej Stanisława Lipno i starszego żołnierza z 52 obozowego batalionu Aleksandra Kaczorkiewicza.

Ustalono jednogłośnie następujące główniejsze postulaty.

Wniosek doktora Chwatas: 1) utworzenie samodzielnej armii polskiej; 2) armia polska ma być jedną $z$ armii składowych Koalicji i powinna działać wyłącznie na froncie austriacko-niemieckim.

Wniosek chorążego Wiśniewskiego ${ }^{9}: 3$ ) armia polska winna się składać $\mathrm{z}$ wszystkich rodzajów broni i być zaopatrzona doskonale w środki techniczne i amunicję. Wniosek chorążego Wolffa: 4) pozostając chwilowo do czasu utworzenia armii polskiej w szeregach armii rosyjskiej uważamy za swój obowiązek podtrzymanie ducha karności i porządku jako najważniejszego czynu naszego bojowego we współczesnej wojnie, czym jedynie w danych warunkach możemy przyjść $z$ pomocą Rządowi Tymczasowemu w jego wzniosłych dążeniach polecając delegatom naszym szerzenie idei obowiązku wśród swoich towarzyszy. Wniosek (dwa słowa nieczytelne): 5) do szeregów armii polskiej ma prawo wstąpić każdy, kto się uważa za Polaka.

Wniosek Matuszewskiego' (?): 6) poruszyć na zjeździe w Mińsku sprawę zabronionej dotychczas korespondencji $z$ krajem domagając się od Rząlu Tymczasowego uregulowania natychmiastowego tej palącej sprawy, w której rozwiązaniu są zainteresowani wszyscy Polacy znajdujący się poza kordonem. Wniosek podpułkownika Aleksandrowicza: 7) o wszczęciu starań w celu poprawy bytu i ulżenia doli jeńców Polaków znajdujących się w niewoli rosyjskiej.

W dniu 16-21 kwietnia odbył się I Zjazd Przedstawicieli Wojskowych Polaków Frontu Zachodniego, na którym opracowano plan organizowania oddziałów (filii) związków na całym froncie i pracy oświatowo-kulturalnej. Wojskowych Polaków armii 2-giej reprezentowali: podpułkownik Aleksandrowicz, kapitan Jaźwiński11, szeregowiec Donalisis ${ }^{12}$, porucznik Matuszewski, żołnierz Ciężarek ${ }^{13}$ i kilku innych oficerów i żołnierzy.

W myśl rezolucji Zjazdu Przedstawicieli Wojskowych Polaków Frontu Zachodniego zwołano na dzień 21 maja (3 czerwca) 1917 roku w Nieświeżu I Zjazd Delegatów Wojskowych Polaków z oddziałów wchodzących w skład armii 2-giej w celu utworzenia przy armii 2-giej filialnego związku Polaków wojskowych Frontu Zachodniego. Na zebranie przybyło 56 przedstawicieli 
od korpusów, dywizji i oddziałów sztabu armii i podległych im oddziałów reprezentujących około 4000 wojskowych Polaków armii 2-giej.

Do prezydium przez aklamację obrano:

na prezesa - podkapitana Miniszewskiego

na zastępców - starszego podoficera Gawora

- urzędnika wojskowego Ryszarda Szymańskiego,

na sekretarza - chorążego Czesława Wolffa, na pomocników - młodszego podoficera wolontariusza Kaczorkiewicza ${ }^{14}$,

- starszego podoficera Krassowskiego ${ }^{15}$,

- starszego podoficera Jana Szklarczyka,

na asesorów - podoficera Tomasza Jarosza,

- szeregowca Antoniego Karpa,

- podchorążego Władysława Frankowskiego.

Zebranie uważając za konieczne połączenie się wszystkich Polaków armii 2-giej postanowiło:

1. Powołać Tymczasowy Komitet Wykonawczy, złożony z pięciu członków i trzech zastępców, któremu dać zupełne pełnomocnictwa w sprawie opracowania formy organizacji Polaków wojskowych armii 2-giej na podstawie Statutu Związków Wojskowych Polaków Frontu Zachodniego.

Na członków Tymczasowego Komitetu Wykonawczego jednogłośnie wybrani zostali: 1) chorąży Szymański, 2) chorąży Wolff, 3) starszy podoficer Gawor, 4) starszy podoficer Krassowski, 5) szeregowiec Donalis; na zastępców: 1) młodszy podoficer Krajewski, 2) starszy podoficer Szklarczyk i 3) młodszy podoficer Górecki ${ }^{16}$.

2. Zobowiązać powołany komitet do zwołania w czasie najbliższym ogólnego zjazdu delegatów wszystkich oddziałów wchodzących w skład armii 2-giej.

3. Upoważnić Tymczasowy Komitet Wykonawczy do przyjmowania w razie potrzeby dodatkowych członków podług uznania komitetu.

Podczas piętnastominutowej przerwy odbyło się pierwsze (nagłe) posiedzenie komitetu. Po wznowieniu obrad chorąży Wolff odczytał postanowienie komitetu. „Tymczasowy Komitet Wykonawczy Wojskowych Polaków Armii 2-giej na pierwszym (nagłym) posiedzeniu postanowił: 1) ogłosić zebranym, że wszystkie zarządzenia komitetu do czasu przyszłego zjazdu powinny mieć bezwzględną moc prawną; 2) polecić wszystkim zebranym delegatom, by niezwłocznie zorganizowali Polaków w swych oddziałach na zasadach Statutu Frontowego ${ }^{17}$, by skłonili drogą agitacji sąsiednie im oddziały do zorganizowania się, pomagając czynnie w tej sprawie; 3 ) Tymczasowy Komitet Wykonawczy ogłasza tymczasowy swój adres: „Zarząd Na- 
czelnika Inżynierów Armii 2-giej, chorąży Czesław Wolff" i pod tym adresem prosi donosić o istniejących i powstających związkach w oddziałach ze wskazaniem prezesa, liczby zorganizowanych osób i adresów związków, a także zwracać się do Tymczasowego Komitetu Wykonawczego w razie potrzeby. Przemówienie chorąży Wolff zakończył tymi słowami: „Tymczasowy Komitet Wykonawczy przystępuje do pracy z wiarą, że wojskowi Polacy dadzą przykład dyscypliny i poczucia obowiązku bezwzględnym i sumiennym spełnianiem wszystkich zarządzeń komitetu, co jest pierwszym warunkiem owocności jego pracy".

$\mathrm{Na}$ wniosek przewodniczącego obrady zakończono powstaniem i hucznymi oklaskami na cześć Wolnej, Niepodległej, Zjednoczonej i Demokratycznej Polski.

Tak powstała naczelna organizacja Związków Wojskowych Polaków Armii 2-giej.

Początek swej działalności Tymczasowy Komitet Wykonawczy zamanifestował wydaniem odezwy: „Do Wszystkich Wojskowych Polaków Armii 2-giej" z gorącym wezwaniem do niezwłocznego zorganizowania się w związki zaczynając od najdrobniejszych oddziałów wojskowych bez względu na rangę i stanowisko.

Na zwyczajnym posiedzeniu w dniu 23 maja (10 czerwca) Tymczasowy Komitet Wykonawczy kooptował do składu komitetu podpułkownika Aleksandrowicza, będącego naówczas na zjeździe ogólnym w Piotrogrodzie ${ }^{18}$, uznając jego współudział w pracach komitetu za niezbędny. Prezydium ukonstytuowało się w sposób następujący: prezes - podpułkownik Aleksandrowicz, wiceprezes - chorąży Wolff, sekretarz - urzędnik wojskowy Stanisław Zieliński.

Postanowiono zawiadomić wyższe władze wojskowe armii 2-giej o powołaniu przez I Zjazd Wojskowych Polaków Armii 2-giej w dniach 21 maja-3 czerwca Tymczasowego Komitetu Wykonawczego i o ukonstytuowaniu się takowego; prezydium polecono zwrócić się do odnośnych władz z prośbą o zalegalizowanie Tymczasowego Komitetu Wykonawczego Wojskowych Polaków Armii 2-giej i o zezwolenie na używanie własnej pieczęci z napisem: „Tymczasowy Komitet Wykonawczy Wojskowych Polaków Armii 2-giej".

W składzie nowego prezydium Tymczasowy Komitet Wykonawczy wydał powtórną odezwę „Do Wszystkich Wojskowych Polaków Armii 2-giej”, opracowaną przez chorążego Wolffa $z$ podaniem obszernego wzoru i zasad organizowania się wojskowych Polaków w związki oraz z ogłoszeniem terminu II Ogólnego Zjazdu Wojskowych Polaków Armii 2-giej. 
Praca Tymczasowego Komitetu Wykonawczego, będąc coraz intensywniejszą, polegała 1) na łączności z Naczelnym Polskim Komitetem Wojskowym w Piotrogrodzie ${ }^{19}$, Zarządem Związków Wojskowych Polaków Frontu Zachodniego w Mińsku, ze związkami wszystkich armii oraz redakcjami wszystkich czasopism polskich; 2) na organizowaniu poszczególnych związków wojskowych Polaków armii 2-giej. W okresie tym bowiem utworzyły się: centrala związków wojskowych Polaków Oddziału Drogowców Armii 2-giej z prezesem inżynierem Słomińskim ${ }^{20}$ na czele, centrala zarządu związków wojskowych Polaków oddziałów podległych Zarządowi Naczelnika Inżynierów Armii 2-giej z prezesem chorążym Czesławem Wolffem, zastępcą urzędnikiem wojskowym Zielińskim i sekretarzem K. ${ }^{21}$ Majem, centrala Związków Wojskowych Polaków 75 Dywizji Piechoty z prezesem księdzem kapelanem Paykertem ${ }^{22}$, Tymczasowy Komitet Wykonawczy Wojskowych Polaków w III Korpusie Syberyjskim, centrala Związków Wojskowych Polaków Korpusu Grenadierów; 3) na polonizowaniu L Korpusu i 171 Dywizji Piechoty, 4) na przeprowadzaniu ${ }^{23}$ związków wojskowych Polaków Armii 2-giej, 5). na kulturalno-oświatowej działalności, przejawiającej się w wygłaszaniu odczytów (odczyt profesora Massoniusa ${ }^{24}$ w dniu 1 sierpnia na temat: „O tworzeniu Państwa Polskiego", urządzony staraniem kółka żołnierzy Polaków przy sztabie armii 2-giej, rozsyłaniu literatury okolicznościowej i czasopism, zwłaszcza organu Naczelnego Polskiego Komitetu Wojskowego ( „Polskie Siły Zbrojne”), organu Zarządu Związków Wojskowych Polaków Frontu Zachodniego („Żołnierz Polski”) oraz organu Tymczasowego Komitetu Wykonawczego ( „Biuletyn”).

$\mathrm{Na}$ posiedzeniu zwyczajnym dnia 5 lipca postanowiono wydawać co tydzień w poniedziałki „Biuletyn” Tymczasowego Komitetu Wykonawczego, wydawanie którego zlecono Komisji Redakcyjnej złożonej z trzech członków, za której podpisem „Biuletyny” miały być przekazywane wszystkim oddziałom wojskowych Polaków armii 2-giej. Do Komisji Redakcyjnej weszli: podpułkownik Aleksandrowicz, chorąży Wolff i podoficer Krassowski. Treść pierwszego numeru, zredagowanego przez chorążego Wolffa, zaakceptowano, poczym chorąży Wolff został odpowiedzialnym redaktorem. Było to pierwsze czasopismo polskie wojskowe, które ${ }^{25}$ i to nawet „Polskie Siły Zbrojne” oraz "Żołnierza Polskiego". W jedności siła! - pod tym hasłem podjął Tymczasowy Komitet Wykonawczy wydawnictwo „Biuletynu”, którego celem było wytworzenie ścisłej łączności między Polakami wojskowymi armii 2-giej i Tymczasowym Komitetem Wykonawczym. Łączność ta miała polegać 1) na powiadamianiu szerszego ogółu o działalności i rozporządzeniach Zarządu Centralnego Związków Wojskowych Polaków w Piotrogrodzie, 
Zarządu Związków Wojskowych Polaków Frontu Zachodniego w Mińsku oraz Naczelnego Polskiego Komitetu Wojskowego; 2) na informowaniu o wypadkach w Ojczyźnie naszej, o życiu na emigracji, o sposobie porozumiewania się z krajem i o wszelkich sprawach dotyczących Polaków żołnierzy; 3) podawaniu do wiadomości rozporządzeń Tymczasowego Komitetu Wykonawczego, obowiązujących dla wszystkich wojskowych Polaków armii 2-giej do czasu powołania stałego zarządu.

Na 18 lipca 1917 r. zwołano II Zjazd Delegatów Wojskowych Polaków Armii 2-giej w celu wyboru komisarza i jego zastępcy jako jedynych przy armii 2-giej reprezentantów Naczelnego Polskiego Komitetu Wojskowego. Jako komisarza powołano podkapitana Matuszewskiego, jako zastępcę chorążego Maruszewskiego ${ }^{26}$, drugim zastępcą był podpułkownik Aleksandrowicz.

Na tymże zjeździe został wybrany stały Zarząd Związków Wojskowych Polaków Armii 2-giej, w skład którego przez aklamację weszli: prezes - podpułkownik Aleksandrowicz, zastępcy prezesa - urzędnik wojskowy Stanisław Zieliński i szeregowiec Donalis, sekretarz - chorąży Czesław Wolff, skarbnik - podoficer Gawor. Nazwa urzędowa, „Zarząd Związków Wojskowych Polaków Armii 2-giej", przy jęta została jednogłośnie.

W celu uzupełnienia składu zarządu postanowiono powołać po jednym przedstawicielu od każdego korpusu, a więc czterech delegatów.

Adres telegraficzny brzmiał: „Sowopolarm ${ }^{27} 2$ ".

Zdarzenia na froncie przyniosły w tym czasie wieść o bohaterskiej walce i śmierci ułanów polskich pod Krechowcami28. Staraniem Zarządu Związków Wojskowych Polaków Armii 2-giej w dniu 27 lipca w Nieświeżu odbyło się uroczyste nabożeństwo żałobne, którego organizacją zajęli się urzędnik wojskowy Zieliński, szeregowiec Donalis i starszy podoficer Gawor.

Dnia 10 sierpnia odbył się w Nieświeżu, w myśl zalecenia Zarządu Związków Wojskowych Polaków Frontu Zachodniego, w celu uzupełnienia składu zarządu, III Zjazd Przedstawicieli Zarządów Centralnych Związków Wojskowych Polaków Armii 2-giej pod przewodnictwem urzędnika wojskowego Zielińskiego. Przybyło dziewięciu delegatów związków dywizyjnych. Przez tajne głosowanie zostali obrani do składu zarządu Frontu Zachodniego podkapitan 299 Dubnieńskiego Pułku Piechoty Józef Lipczyński i podoficer 4 Nieświeskiego Pułku Grenadierów Stanisław ${ }^{29}$ lewicz.

Na tymże posiedzeniu poruszono sprawę wyborów do konstytuanty rosyjskiej uznając większością głosów, że Polacy - mieszkańcy Królestwa Polskiego, jako obywatele państwa niepodległego, nie powinni w wyborach tych brać udziału; w wyniku przy jęto wniosek urzędnika Zielińskiego, aby Zarząd Związków Wojskowych Polaków Armii 2-giej zwrócił się po dyrektywy do 
Naczelnego Polskiego Komitetu Wojskowego, co też uczyniono. Naczelny Polski Komitet Wojskowy zatwierdził powyższą uchwałę, ogłaszając takową w komunikatach i czasopismach.

Nastrój polityczny stawał się dla sprawy formowania polskiej siły zbrojnej wrogim; minister wojny Kiereński ${ }^{30}$ odmówił zalegalizowania Naczelnego Polskiego Komitetu Wojskowego, tym motywu jąc odmowę, że Naczelny Polski Komitet Wojskowy mimo zezwolenia Rządu Tymczasowego na formowanie jednego tylko korpusu, formuje siłę zbrojną ze wszystkich Polaków pragnących przejść do oddziałów polskich, co wyniosłoby więcej niż jeden korpus.

Deklaracja Rządu Tymczasowego, zapewniająca nam niepodległość i prawo samostanowienia, została przez to faktycznie skasowaną. Fałszywy stosunek do nas ludu rosyjskiego ujawniły takie czyny, jak rewizja dokonana w nocy z 30 na 31 sierpnia w lokalu Naczelnego Polskiego Komitetu Wojskowego przez komisję Rady Delegatów Robotniczych i Żołnierskich, aresztowanie starszego doktora i oficerów polskich pułku zapasowego w Biełgorodzie w nocy przy użyciu siły zbrojnej z rozkazu sztabu Siódemki rewolucyjnej miasta Biełgorodu ${ }^{31}$, albo zabronienie przez członka rosyjskiego komitetu wykonawczego armii 2-giej sekretarzowi Zarządu Związków Wojskowych Polaków Armii 2-giej używania języka polskiego w rozmowie telefonicznej (rozporządzenia) ${ }^{32}$.

Wobec tych oburzających gwałtów Zarząd Wojskowych Polaków Armii 2-giej wystosował kategoryczny, gorący protest, zredagowany przez zastępcę prezesa, urzędnika Zielińskiego, za numerem 606, do prezesa Rady Ministrów, do Centralnego Komitetu Wykonawczego Rad Delegatów Robotniczych i Żołnierskich w Piotrogrodzie i do Komitetu Siedmiu w Biełgorodzie ${ }^{33} \mathrm{z}$ żądaniem natychmiastowego zalegalizowania Naczelnego Polskiego Komitetu Wojskowego i rozstrzygnięcia sprawy formowania polskiej siły zbrojnej zgodnie z uchwała I Ogólnego Zjazdu Wojskowych Polaków w Piotrogrodzie.

Protesty te dotarły również do wszystkich związków wojskowych Polaków na łamach „Biuletynu”, który od czasu przeniesienia biura Zarządu Związków Wojskowych Polaków Armii 2-giej w dniu 3 września z Nieświeża do Słucka został rozszerzony przez wprowadzenie działu z życia związków i drukowania artykułów aktualnych.

Jednocześnie $z$ powyżej wymienionymi protestami Zarząd Związków Wojskowych Polaków Armii 2-giej wystosował pismo zredagowane przez wiceprezesa urzędnika Zielińskiego i sekretarza chorążego Wolffa do Naczelnego Polskiego Komitetu Wojskowego z wyrazami najwyższej pogardy dla 
czynu tych Polaków ${ }^{34}$, którzy fałszywie oskarżyli Naczelny Polski Komitet Wojskowy o utrzymywaniu jakoby stosunków ze Stawką 35 i kompromitującej Komitet korespondencji i brali wespół z komisją śledczo-prawną Wszechrosyjskiego Komitetu Wykonawczego Rad Robotniczych i Żołnierskich Delegatów udział czynny w rewizji ksiąg i dokumentów Naczelnego Polskiego Komitetu Wojskowego.

Działalność Zarządu Związków Wojskowych Polaków Armii 2-giej dosięgała swego zenitu. Zarząd stał się dla wszystkich związków wojskowych Polaków armii 2-giej prawdziwym sztabem, w którym zbiegały się nici kontaktu z licznymi związkami armii 2-giej: codziennie napływały stosy papierów, podania o przeniesienie $\mathrm{z}$ oddziałów rosyjskich do polskiej siły zbrojnej; wymienne egzemplarze polskich i rosyjskich dzienników i tygodników; broszury okolicznościowe i książki ofiarowywane do przesłania dookopów; mnóstwo interesantów, oficerów, żołnierzy, wygnańców zgłaszało się po informacje, zaświadczenia, gazety. Codziennie dziesiątki pakietów z odpowiedziami, okólnikami, odezwami, setki opasek z gazetami, a zwłaszcza „Biuletynu”, szło na pocztę polową. Pełen czynu zastępca prezesa od dnia 15 maja sekretarz zarządu, urzędnik wojskowy Stanisław Zieliński pracował do późnej nocy redagując odezwy, depesze, odpowiedzi, płomienne artykuły i protesty.

Dzień 2 (15) października, w setną rocznicę zgonu Tadeusza Kościuszki, uczcił śmierć z inicjatywy Zarządu Związków Wojskowych Polaków Armii 2-giej urządzeniem uroczystego obchodu, na który złożyło się: przed południem nabożeństwo żałobne, zaś wieczorem „Żywe słowo o Kościuszce” wypowiedziane przez pana Zielińskiego, Prolog z „Dyktatora” Żuławskiego ${ }^{36}$ - odegrany przez grono amatorów oraz dział koncertowy.

W miarę wyjazdu wielkiej liczby członków związków wojskowych Polaków armii 2-giej do oddziałów wojskowych I Polskiego Korpusu ${ }^{37}$ Zarząd Związków Wojskowych Polaków Armii 2-giej polecił związkom dokonywać wyboru brakujących członków, gdzie zostały zdekompletowane ich zarządy, wymagając w celu prowadzenia statystyki powołanych do polskich sił zbrojnych nadsyłania ścisłych wiadomości o ilości oficerów i żołnierzy Polaków, którzy wyjechali na służbę do oddziałów wojskowych I Korpusu Polskiego.

W połowie października Zarząd Związków Wojskowych Polaków Armii 2-giej z powodu wystąpienia podoficera Gawora i szeregowego Donalisa ukonstytuował się w sposób następujący:

prezesem został - podpułkownik Aleksandrowicz, zastępcami - chorąży Wolff i kooptowany

$$
\text { - sędzia L. Maleszewski }{ }^{38} \text {, }
$$


skarbnikiem - kooptowany chorąży Kowalewski³, sekretarzem - urzędnik wojskowy Zieliński, delegatem od L Korpusu - żołnierz Władysław Cichowski.

W tym składzie prezydium zarządu wystosowało protest do Centralnego Komitetu Wykonawczego Rad Delegatów Robotniczych i Żołnierskich przeciwko warunkom pokoju demokracji rosyjskiej danym delegatowi na konferencję Koalicji antyniemieckiej M. I. Skobielewowi ${ }^{40}$, które ograniczały się do żądania wycofania wojsk niemieckich z granic Rosji, pozostawiając Poznańskie i Galicję pod władzą Austrii i Prus.

Następnie prezydium wydelegowało chorążego Wolffa na konferencję do Piotrogrodu na dzień 27-31 października 1917 r., dając instrukcje w sprawach wielkiej wagi, które miały być poruszone na zjeździe. Wspomnę tylko niektóre, a mianowicie.

1. „W sprawie legalizacji związków wojskowych Polaków w armii rosyjskiej domagać się całkowitej samodzielności działania dla związków oraz zwolnienia prezydium od zajęć służbowych".

2. W kwestii stosunku Naczelnego Polskiego Komitetu Wojskowego do ugrupowań politycznych stać ponad wszelkimi partiami utrzymując kontakt z tymi, które popierają zadania i cele Polaków wojskowych.

3. W sprawie taktyki w postępowaniu do Rządu Tymczasowego odmawiającego legalizacji Naczelnego Polskiego Komitetu Wojskowego i związków, utrudniającego formowanie polskiej siły zbrojnej, prześladu jącego jeńców Polaków przez cofnięcie nadanych 30 czerwca ulg Polacy wojskowi w wypadku, jeśli rząd nie zmieni swego postępowania, winni wykorzystać całkowicie swe prawa wypływające $z$ tytułu obywateli państwa niepodległego aż do wystąpienia $z$ szeregów armii rosyjskiej włącznie.

4. Uważać Radę Deputatów Robotniczych i Żołnierskich, która w początkach rewolucji ogłosiła prawa narodu polskiego do niepodległości i zjednoczenia, za instytucję prywatną, wobec gwałtu na Naczelnym Polskim Komitetem Wojskowym i chęci ograniczenia granic Polski tylko do zaboru rosyjskiego.

5. W sprawie taktyki w postępowaniu do państw Koalicji żądać, aby mocarstwa Koalicji uroczystym aktem rządów stwierdziły prawo Polski do niepodległości i zjednoczenia i zamieściły w szeregu zasadniczych celów wojny postulat rozwiązania sprawy państwa polskiego w duchu naszych żądań.

6. Uznać zwołanie II Ogólnego Zjazdu Delegatów Wojskowych Polaków za nadzwyczaj pożądane.

Konferencja ta odbyła się wśród odgłosów walk Rządu Tymczasowego z maksymalistami ${ }^{41}$, którzy wzięli górę w walce, usuwając Rząd Tymczasowy 
i wprowadzając w życie za pomocą terroru idee socjalistyczne. Rozpoczęła się w kraju zawierucha ${ }^{42}$, wzniecając pożar anarchii, dozorganizację armii rosy jskiej i porządku społecznego.

W tak ciężkich i zawikłanych okolicznościach Zarząd Związków Wojskowych Polaków 2 Armii 2-giej zwołał na dzień 12 listopada w Słucku ogólne zgromadzenie Polaków słuckiej załogi dla obznajomienia ich z bieżącym momentem politycznym i rezolucjami konferencji piotrogrodzkiej, sprawozdania której zajmująco, wymownie i wyczerpująco udzielił chorąży Wolff.

W parę dni później, bo 15-17 listopada odbył się w Słucku IV Zjazd Delegatów Wojskowych Polaków Armii 2-giej pod przewodnictwem prezesa zarządu podpułkownika Aleksandrowicza, zastępcy chorążego Wolffa, sekretarzy urzędnika Zielińskiego i wolontariusza Matuszewskiego ${ }^{43}$. Z pomiędzy czternastu uchwał zjazdu na szczególną uwagę zasługuje rezolucja: „Iż wojskowi Polacy jako obywatele Niepodległego Państwa Polskiego winni niezwłocznie opuścić szeregi rosyjskie przenosząc się do polskiej siły zbrojnej".

W prezydium zarządu zaszły zmiany uradzone na zjeździe wobec tego, że podpułkownik Aleksandrowicz zastosowując się do życzeń Naczelnego Polskiego Komitetu Wojskowego, aby jego przedstawiciele nie byli prezesami związków, wystawioną przez zjazd kandydaturę na prezesa cofnął; na prezesa wybrano pułkownika Eugeniusza Szpręglewskiego, na zastępców chorążego Wolffa i sędziego Maleszewskiego, na sekretarza urzędnika wojskowego Zielińskiego i na skarbnika wolontariusza Tadeusza Matuszewskiego.

Wszystkie związki wojskowych Polaków armii 2-giej w osobach swych delegatów potwierdzały uznanie Naczelnego Polskiego Komitetu Wojskowego za władzę naczelną $\mathrm{z}$ wyjątkiem Związku Żołnierzy Polaków przy Sztabie Armii, który w październiku 1917 r. przyłączył się do Komitetu Głównego (lewicy) w Piotrogrodzie ${ }^{44}$.

Jednocześnie obrano delegatów na zjazd frontowy: pułkownika Szpręglewskiego, chorążego Wolffa, inżyniera Słomińskiego, podoficera Zendlewicza $^{45}$, felczera Urbańskiego ${ }^{46}$, sztabskapitana Matuszewskiego, urzędnika Framaszczuka $^{47}$, szeregowego Cichowskiego ${ }^{48}$, pisarza Nowickiego ${ }^{49}$, doktora Chwata i podoficera Szklarczyka ${ }^{50}$. Zastępcami delegatów: urzędnika Zielińskiego, chorążego Ścięgosza ${ }^{51}$ i kaprala Jarkiewicza ${ }^{52}$.

II zjazd frontowy odbył się w Mińsku Litewskim dnia 26 listopada-2 grudnia reprezentując 23700 zorganizowanych żołnierzy i oficerów.

W miarę rozrastania się anarchii bolszewickiej coraz częściej nadchodziły wieści o zamachach na polskie siły zbrojne.

Depesza zwierzchniego głównodowodzącego Krylenki ${ }^{53} \mathrm{nr}$ 8728, nakazująca powstrzymać dalsze wydzielanie do polskich i ukraińskich sił zbroj- 
nych, a istniejące już jednostki wojskowe przeformować na zasadach „demokratycznych", wskazanych w rozkazie Krylenki nr 12 oraz zakazująca zwoływania zjazdów narodowościowych, dopełniła czarę goryczy wychylanej wciąż przez Polaków mimo gładkich słówek i obietnic rewolucji rosyjskiej.

Posypały się protesty. Jednym z pierwszych i najbardziej piętnujących Krylenkę, była depesza nr 1311, wysłana przez Zarząd Związków Wojskowych Polaków Armii 2-giej, zredagowana przez podpułkownika Aleksandrowicza, pułkownika Szpręglewskiego, urzędnika wojskowego Zielińskiego, chorążego Wolffa i sędziego Maleszewskiego, podpisana przez prezesa pułkownika Szpręglewskiego i sekretarza Zielińskiego.

Rewolucyjny komitet armii 2-giej zaaresztował oryginał depeszy, o czym zarząd powiadomiony został przez urzędnika telegrafu sztabowego, gorącego patriotę Polaka, człowieka odwagi cywilnej, pana Daniela Kamińskiego, który rozesłał protest telegraficznie w tajemnicy przed kontrolą bolszewicką do wszystkich krańców Rosji pod numerem 1331.

Zawdzięczając interwencji chorążego Wolffa, który zdołał telefonicznie przekonać komisarza bolszewickiego o prawach Polaków do samookreślenia, niejednokrotnie podkreślanych przez demokrację rosyjską, oryginał został zwrócony i przechowuje się w aktach zarządu.

Jednocześnie, na nadzwyczajnym posiedzeniu w dniu 9 grudnia 1917 r. zarząd postanowił, mimo zakazu Krylenki, w dalszym ciągu prowadzić rozpoczęte prace wydzielając Polaków drogą rewolucyjną. W wykonaniu tej uchwały wielką pomoc okazał powyżej wymieniony urzędnik telegrafów, później urzędnik do zleceń przy naczelniku Wydziału Administracyjnego Zarządu do Spraw Cywilnych pan Kamiński wysyłając na własną odpowiedzialność niejedną depeszę pilną, decydującą, podlegającą zatrzymaniu przez kontrolę bolszewicką.

W czasie tak gorącej pracy zarządu i walki z przeciwnościami sekretarz Zieliński, który całą duszą oddany był sprawom zarządu, sprężyście i dokładnie kierując kancelarią, nie szczędząc trudów i wywczasu dla sprawy ogólnej, opuścił zarząd wobec objęcia mandatu członka zarządu Związków Wojskowych Polaków Frontu Zachodniego, do którego wybrany został na II Zjeździe Delegatów Wojskowych Polaków Frontu Zachodniego. Opuścił $\mathrm{w}$ tej myśli, iż praca $\mathrm{w}$ zarządzie frontowym da szersze pole działalności jego dalszej walki i niestrudzonej energii.

Sekretariat objął wiceprezes zarządu chorąży Wolff. W coraz to trudniejszych warunkach, stwarzanych przez moment polityczny, sterem zarządu kierowali śmiało, ze szczerym oddaniem się sprawie polskiej, prezes pułkow- 
nik Szpręglewski, wiceprezes sędzia Maleszewski i sekretarz chorąży Wolff wespół z przedstawicielem Naczelnego Polskiego Komitetu Wojskowego na armię 2-gą podpułkownikiem Aleksandrowiczem.

Wobec zastraszającego topnienia armii rosyjskiej Zarząd Związków Wojskowych Polaków Armii 2-giej postanowił wykorzystać sytuację w celu spolonizowania batalionów obozowych ${ }^{54}$ i wydobycia koni $z$ oddziałów rosyjskich. W tym celu zwołano na dzień 22 grudnia przedstawicieli od każdego transportu ${ }^{55}$ dla omówienia środków dopięcia celu. Zebranie jednogłośnie uchwaliło: „Transportów formowanych w Polsce nie rozformowywać, a cały majątek zostanie w rękach żołnierzy Polaków dla powrotu do kraju ludzi wraz $\mathrm{z}$ inwentarzem i całym majątkiem w celu oddania ludności tych okolic, gdzie transporty były formowane". Dla wykonania powyższej uchwały powołano komisję złożoną z przedstawicieli po jednym z każdego obozowego batalionu.

Tymczasem z powodu depeszy nr 1311 ponad zarządem zbierały się chmury. Wreszcie w dniu 27 grudnia z rozporządzenia Krylenki zostali zaaresztowani przez Komitet Rewolucyjny Armii 2-giej przedstawiciel Naczelnego Polskiego Komitetu Wojskowego przy armii 2-giej podpułkownik Aleksandrowicz i prezes Zarządu Związków Wojskowych Polaków Armii 2-giej pułkownik Szpręglewski56 i wysłani do Mińska, do więzienia. Rozkaz zaaresztowania dotyczył również urzędnika wojskowego Zielińskiego, który w tym czasie znajdował się w Mińsku.

W parę dni potem telegraf przyniósł wiadomość o zaaresztowaniu z rozkazu Krylenki sześciu członków Naczelnego Polskiego Komitetu Wojskowego.

W tak krytycznej chwili, niepewni jutra pod względem wolności osobistej, na czele zarządu pozostali tylko chorąży Wolff i sędzia Maleszewski, którzy wydali natychmiast odezwę do wszystkich związków wojskowych Polaków armii 2-giej o zaaresztowaniu obu pułkowników z wezwaniem o zareagowanie na taki oburzający gwałt, zaś w artykule pod tytułem "Gwałty bolszewików”, umieszczonym w numerze 25-27 „Biuletynu” chorąży Wolff jędrnie i dobitnie zaprotestował przeciwko aresztowi pułkownika Szpręglewskiego i podpułkownika Aleksandrowicza, tak śmiało, odważnie, z zaparciem się siebie występujących w obronie naszych wspólnych interesów.

$\mathrm{Na}$ nadzwyczajnym posiedzeniu uznano za konieczne zwołanie na 15 stycznia 1918 r. V Ogólnego Zjazdu Wojskowych Polaków Armii 2-giej; ażeby całą powagą zjazdu zareagować na areszty po całkowitym wyjaśnieniu sytuacji. Powołano komisję zjazdową z pięciu członków: chorążego Wolffa, 
sędziego Maleszewskiego, podoficera Gawora, szeregowego Plocha ${ }^{57}$ i jednego przedstawiciela Związku Wojskowych Polaków XV Inżynieryjnej Brygady. Pod przewodnictwem chorążego Wolffa komisja wyznaczyła dzień zjazdu na 15 stycznia.

Obrady zjazdu trwały trzy dni pod przewodnictwem inżyniera Słomińskiego, znamionując burzliwą wymianę myśli pomiędzy wyznawcami rozmaitych kierunków politycznych wobec zbliżających się zatargów między korpusem polskim a maksymalistami ${ }^{58}$.

Następujące z błyskawiczną szybkością wypadki, wojna korpusu z bolszewikami, ukazały w końcu stycznia możliwość zbrojnego starcia wojsk polskich $\mathrm{z}$ rosyjskimi w okolicach Słucka. W celu zapobieżenia przelewowi krwi Zarząd Związków Wojskowych Polaków Armii 2-giej na nadzwyczajnym posiedzeniu w dniu 20 stycznia 1918 r. postanowił zwrócić się do dowódcy armii i Komitetu Rewolucyjnego Armii 2-giej z propozycja wysłania do twierdzy Bobrujsk - miejsca skoncentrowania naówczas polskiej siły zbrojnej, delegacji polsko-rosyjskiej, która po zbadaniu bezstronnym sprawy wpłynęłaby na załagodzenie zaostrzonych stosunków pomiędzy wojskami, czym ochroniłaby ludność cywilna polska od możliwych gwałtów. Dobry zamiar nie doszedł do skutku wobec skomplikowania wypadków. Z tego samego powodu nie mógł dojść do skutku II Ogólny Zjazd Wojskowych Polaków, naznaczony na dzień 20 lutego 1918 r.

Czynności zarządu stopniowo zamierały: wojna polsko-rosyjska ${ }^{59}$, przerwanie komunikacji osobowej i pocztowej zmuszały do biernego prawie wyczekiwania zmiany i wy jaśnienia sy tuacji politycznej; wobec zakusów bolszewików na wolność osobistą przeciwników zarządu oraz obawy rewizji lokalu zarządu trzeba było ukrywać się po domach prywatnych oraz ukrywać akta, dzienniki, pieczęcie zarządu.

Praca więc przycichła, lecz nie ustała; niejedna cenna wskazówka, rada, ostrzeżenie wynikłe $z$ obserwacji ruchów bolszewików zostały z inicjatywy podpułkownika Aleksandrowicza, sędziego Maleszewskiego i chorążego Wolffa, pod grozą niebezpieczeństwa, przesłane do Bobrujska, zawdzięczając odwadze i uprzejmości panów Franaszczuka, urzędnika wojskowego członka zarządu wojskowych Polaków Mancewicza ${ }^{60}$, Janowskiego ${ }^{61}$ i ...62

Około 20 lutego Niemcy zaczęli obejmować Mińszczyznę, wobec czego rządy bolszewickie przystąpiły do likwidacji opuszczając zajmowane placówki.

Wówczas w Słucku wobec bezrządu ster miasta i spokojnej ludności wziął Zarząd Związków Wojskowych Polaków Armii 2-giej w swe ręce utworzywszy polską komendanturę, na czele której stanął podpułkownik Ale- 
ksandrowicz wespół z chorążym Wolffem, Stanisławem Tomazewiczem. Komendantura zorganizowała milicję polską, zaś część pozostałych członków zarządu bolszewickiego rozbrojono i aresztowano, zdobytą broń i samochody przesłano do korpusu polskiego.

Działalność zarządu specjalnie zredukowała się do wydawania zaświadczeń obywatelstwa polskiego tym, którzy wobec pogłosek o zmianie jakoby byłej granicy, opuszczali Słuck w kierunku zachodnim w nadziei dotarcia do kraju oraz przepustek obywatelom państwa rosy jskiego, podążającym na wschód przed nadejściem Niemców.

W parę godzin po wejściu Niemców do Słucka nadjechały i polskie oddziały, sztab których wespół z polską komendanturą rządził w Słucku do dnia 15 marca. W tym dniu Zarząd Związków Wojskowych Polaków Armii 2-giej został ostatecznie zlikwidowany, zaś cały inwentarz przewieziony do Bobrujska.

Pieczęć zarządu z orłem polskim po raz ostatni stwierdziła w tym dniu 15 marca 1918 r. zaświadczenie na wolny przejazd do Bobrujska zastępcom prezesa zarządu podporucznikowi Wolffowi i sędziemu Maleszewskiemu oraz gronu osób, które szczerze aż do ostatniej chwili wytrwały na polskim posterunku w Słucku.

Związek Wojskowych Polaków Armii 2-giej dostarczył I Polskiemu Korpusowi wielu ludzi, którzy zajęli w nim wybitne stanowiska, a mianowicie: pułkownik Szpręglewski - szef sztabu I Polskiego Korpusu, pułkownik Wroczyński63 - naczelny inżynier korpusu, podpułkownik Aleksandrowicz naczelnik Zarządu Administracyjnego, później szef Oddziału Wykonawczego, podporucznik Szulborski64 - prokurator korpusu, sędzia Maleszewski - naczelnik Wydziału Sądowo-Prawnego i wielu innych.

W tym miejscu należą się słowa uznania prawdziwie szanowanej i szczerą sympatią otoczonej osobie podpułkownika Aleksandrowicza.

Podpułkownik Aleksandrowicz wyróżniał się zawsze spośród licznego grona oficerów Polaków sztabu armii 2-giej. Nie bacząc na długoletnią służbę wojskową $\mathrm{z}$ dala od kraju, nie zatracił ducha polskiego podkreślając stale i szczycąc się tym, że jest Polakiem. Po wybuchu rewolucji stanął na czele grupy ludzi, których celem było skupienie Polaków pracując od tąd wytrwale w obranym kierunku. Początkowo, gdy zdawało się, że z Tymczasowym Rządem rosyjskim można będzie dojść do porozumienia, starał się ułatwić kroki nowopowstającej organizacji u władz rosyjskich, chcąc ją zalegalizować, a następnie, gdy wszelkie usiłowania porozumienia okazały się bezskuteczne, szedł prosto do celu nie zważając na rozkazy władz. W końcu został zaaresztowany i pozbawiony stanowiska, które zajmował w sztabie. 
Gorący patriota, człowiek nieskazitelnej uczciwości, ofiarny, zasilał swą pomocą wszystkie organizacje polskie, działające na terenie sztabu armii 2-giej, zachęcając do pracy w tym kierunku swoich kolegów. Cieszył się zasłużoną miłością i szacunkiem wśród Polaków wojskowych, dla których każde słowo podpułkownika Aleksandrowicza było rozkazem.

Spośród członków i kierowników zarządów poszczególnych związków na froncie zapałem, inicjatywą i pracą wyróżnili się:

1) L Korpus:

75 Dywizja Piechoty - ksiądz kapelan Paykert, podkapitan Ignacy Matuszewski, wolontariusz Tadeusz Matuszewski, podkapitan Józef Lipczyński, szeregowiec Władysław Cichowicz;

129 Dywizja Piechoty - porucznik Brzozowski65, żołnierz Barszczew$\mathrm{ski}^{66}$

178 Dywizja Piechoty - porucznicy Kozłowski67 i ski68;

2) III Korpus:

w sztabie korpusu podoficer Jan Zygmunt;

w 7 Syberyjskiej Dywizji Strzelców chorąży Michalewski69;

w 8 Syberyjskiej Dywizji Strzelców doktor Borkowskiº;

w 7 Turkiestańskiej Dywizji Strzelców podoficer Kamiński ${ }^{71}$;

w 17 Syberyjskiej Dywizji Strzelców, 68 Syberyjskim Pułku chorąży Nitecki;

3) Korpus Grenadierów: w dywizji grenadierów chorąży Żakiewicz ${ }^{72}$, porucznik Stanisław Zendlewicz, ten ostatni niestrudzony; 1 Syberyjska Dywizja Strzelców - pułkownik Szpręglewski, podpułkownik Ojrzanowski³ i porucznik Szwede ${ }^{74}$

4) IX Korpus:

7 Dywizja Piechoty - lekarz weterynarii doktor Mazurkiewicz ${ }^{75}$,

12 Dywizja Piechoty - doktor Gorczycki76 i żołnierz Ciężarek;

IX moździerzowy dywizjon - porucznik Średziński77 i żołnierz Kolar$\mathrm{ski}^{78}$

5) oddziały naczelnika inżynierów armii 2-giej - chorążowie Stanisław Maruszewski i Tadeusz Kobyliński, podoficer Maliszewski;

6) Centrala Związków Wojskowych Polaków Oddziału Drogowców Armii 2-giej - prezes inżynier Zygmunt Słomiński, inżynier Zubelewicz ${ }^{79}$;

7) bataliony obozowe:

II batalion obozowy - chorąży Kreczmar ${ }^{80}$;

LII batalion obozowy - chorąży Józef Ścięgosz;

XI batalion obozowy - chorąży Szalkiewicz ${ }^{81}$;

XII batalion obozowy kapitan Pieczkowski ${ }^{82}$; 
8) polowe piekarnie: urzędnik Zamecznik ${ }^{83}$, podoficer Szukaczuk ${ }^{84}$ i żołnierz Bocian $^{85}$.

Kończąc opis działalności Zarządu Związków Wojskowych Polaków Armii 2-giej składam prawdziwego uznania hołd tym kierownikom, pracownikom zarządu, którzy odznaczając się skromnością, lecz wybitnymi zaletami ducha i umysłu, z całym oddaniem się sprawie formowania polskiej siły zbrojnej, bezinteresownie, z zapałem, poczuciem sprawiedliwości i troski o dobro społeczne, mając przede wszystkim na względzie, mimo trudności, mimo niebezpieczeństwa aresztowania, niewygody, kierowali zarządem ułatwiając życzącym tego sobie przechodzenie do polskich oddziałów, wysoko reprezentowali i nieśli polski sztandar wśród rozszalałego morza anarchii rosyjskiej, czyhającej wespół z Niemcami na zagładę Tej, Która jeszcze nie zginęła, Polski.

24 czerwca 1918 r.

Oryginał, rękopis.

CAW, Kolekcje, t. 400/ 1615.
Ludzie czynu żyją.

Porucznik Mieszkowski ${ }^{86}$

1 Autor miał na myśli Proklamację rosyjskiego Rządu Tymczasowego z 30 marca 1917 r., publikowaną niekiedy z datą 29 marca 1917 r., por. Powstanie II Rzeczypospolitej. Wybór dokumentów 1866-1925. Pod redakcją Haliny Janowskiej i Tadeusza Jędruszczaka, Warszawa 1981, s. 322.

2 Określenie nieścisłe. Winno być sztabskapitan. Imienia tegoż oficera nie udało się ustalić.

3 Chorąży Wolft miał na imię Czesław.

4 Chodzi o chorążego Ryszarda Szymańskiego.

5 Chodzi o urzędnika wojskowego Stanisława Zielińskiego.

6 Zarząd Jenerała Kwatermistrza to jednostka zajmująca się w sztabach armii rosyjskiej planowaniem operacyjnym.

7 Chodzi o podpułkownika Pawła Aleksandrowicza.

8 Imienia doktora Chwata nie udało się ustalić.

9 Imienia chorążego Wiśniewskiego nie udało się ustalić.

10 Chodzi prawdopodobnie o sztabskapitana Ignacego Matuszewskiego, później wysokiego oficera polskiego wywiadu wojskowego, piłsudczyka, w latach 1929-1931 ministra skarbu, w latach 1932-1936 naczelnego redaktora „Gazety Polskiej”, podczas drugiej wojny światowej przebywającego na emigracji w Stanach Zjednoczonych.

11 Chodzi o Bolesława Jaźwińskiego, późniejszego generała Wojska Polskiego.

12 Imienia Donalisa nie udało się ustalić.

13 Imienia Ciężarka nie udało się ustalić.

14 Imienia Kaczorkiewicza nie udało się ustalić. 
15 Pełnego imienia B. Krassowskiego nie udało się ustalić.

16 Pełnego imienia podoficera A. Góreckiego nie udało się ustalić.

17 Chodzi o statut Związku Wojskowych Polaków Frontu Zachodniego.

18 Chodzi o I Ogólny Zjazd Wojskowych Polaków w Piotrogrodzie; jego obrady trwały od 7 do 22 czerwca 1917 r.

19 Chodzi o tak zwany Naczpol, który działał pod kierunkiem chorążego Władysława Raczkiewicza, Prezydenta RP na emigracji podczas drugiej wojny światowej.

20 Wzmianka dotyczy inżyniera Zygmunta Słomińskiego.

21 Pełnego imienia w dokumencie brak.

22 Chodzi o kapelana Jana Paykerta zmobilizowanego do armii rosyjskiej w diecezji kieleckiej.

23 Dalej w tekście dwa nieczytelne słowa.

24 Chodzi o filozofa, późniejszego profesora Uniwersytetu Wileńskiego Mariana Massoniusa (1862-1945).

25 Dalej w tekście parę nieczytelnych słów.

26 Wzmianka dotyczy chorążego Stanisława Maruszewskiego.

27 Chodzi prawdopodobnie o skrót słów: Sowiet Polowej Armii 2-giej, czyli o Radę Żołnierską Armii 2-giej.

28 Chodzi o bój stoczony 24 lipca 1917 r. pod Krechowcami leżącymi na zachodnich przedpolach Stanisławowa przez Pułk Ułanów Polskich pułkownika Bolesława Mościckiego z grupa wojsk niemieckich generała Karla Litzmanna.

29 Pierwsze litery nazwiska nieczytelne.

30 Chodzi o ministra Aleksandra Kiereńskiego, późniejszego premiera rosyjskiego.

31 O tych wydarzeniach szerzej: M. Wrzosek, Przyczynek do historii 1 Rewolucyjnego Putku Polskiego, „Przegląd Historyczny” 1957, z. 4, s. 722-723.

32 Dalej parę nieczytelnych słów.

33 Por. przypis nr 31.

34 Chodzi o działaczy Komitetu Głównego Związków Wojskowych Polaków - Lewicy, którzy woleli walczyć za sprawę cudzej rewolucji niż o niepodległość własnej ojczyzny. Ta antypolska organizacja powstała w wyniku rozłamu, na jaki się poważyła podczas obrad I Ogólnego Zjazdu Wojskowych Polaków w Piotrogrodzie. Prowodyrem rozłamu był por. Roman Łągwa, późniejszy wysoki komisarz Armii Czerwonej, który za swoje rewolucyjne usługi otrzymał należną zapłatę 8 lutego 1938 r. Rehabilitowany pośmiertnie po XX Zjeździe KPZR.

35 Chodzi o sztab głównodowodzącego armii rosyjskiej. Na początku pierwszej wojny światowej, gdy głównodowodzącym armii rosyjskiej był wielki książę Mikołaj Mikołajewicz, a szefem sztabu drań Mikołaj Januszkiewicz (wydał zarządzenie w sprawie systematycznego palenia osad podczas odwrotu wojsk rosyjskich z Królestwa Polskiego w 1915 r.), wówczas ten sztab przebywał w Baranowiczach. Potem, po objęciu dowództwa przez samego cara Mikołaja II, a stanowiska szefa przez generała Michała Aleksiejewa sztab głównodowodzącego wojsk rosyjskich przeniósł się do Mohylewa nad Dnieprem.

36 Autorem tego dramatu był Jerzy Żuławski (1874-1915).

37 Chodzi o I Korpus Polski generała Józefa Dowbor-Muśnickiego w Bobrujsku.

38 Pełnego imienia sędziego L. Maleszewskiego nie udało się ustalić.

39 Imienia chorążego Kowalewskiego nie udało się ustalić. 
40 Chodzi o Matwieja I. Skobielewa.

41 To określenie dotyczy bolszewików.

42 Ta wzmianka dotyczy rewolucji październikowej.

43 Chodzi o ochotnika Tadeusza Matuszewskiego; ochotników nazywano wówczas wolontariuszami.

44 Por. przypis nr 34.

45 Chodzi o podoficera Stanisława Zendlewicza.

46 Imienia felczera Urbańskiego nie udało się ustalić.

47 Imienia urzędnika Franaszczuka nie udało się ustalić.

48 Wzmianka dotyczy szeregowca Władysława Cichowskiego.

49 Imienia pisarza wojskowego (kancelisty) Nowickiego nie udało się ustalić.

50 Imienia podoficera Szklarczyka nie udało się ustalić.

51 Chodzi o podchorążego Józefa Ścięgosza.

52 Imienia kaprala Jarkiewicza nie udało się ustalić.

53 Wzmianka dotyczy głównodowodzącego armii rosyjskiej chorążego Mikołaja Krylenki, powołanego na to stanowisko przez Radę Komisarzy Ludowych; zapisał się w historii głównie tym, że albo przyczynił się do zamordowania w Mohylewie generała Mikołaja Duchonina (pełnił obowiązki szefa Stawki - por. przypis nr 35), albo zabójstwu Duchonina przez marynarzy nie zapobiegł. Zamordowany w 1938 r. na rozkaz Stalina, ale po 1956 r. zrehabilitowany.

54 Tak w tekście, powinno być taborowy.

55 Określenie stosowane wobec najniższych jednostek wojskowych w wojskach taborowych armii rosyjskiej.

56 Wzmianka dotyczy podpułkownika Eugeniusza Szpęglewskiego, późniejszego szefa sztabu w korpusie generała Dowbor-Muśnickiego.

57 Imienia szeregowego K. Plocha nie udało się ustalić.

58 Chodzi o starcia zbrojne I Korpusu Polskiego z siłami Armii Czerwonej (starcia te i obecnie sa traktowane przez niektórych historyków polskich jako początek wojny polsko-sowieckiej; nie maja racji). Szerzej o starciach I Korpusu Polskiego: M. Wrzosek, Polskie korpusy wojskowe w Rosji w latach 1917-1918, Warszawa 1969, s. 125-135.

59 Przesadne określenie; por. poprzedni przypis.

60 Imienia urzędnika wojskowego Mancewicza nie udało się ustalić.

61 Imienia Janowskiego nie udało się ustalić.

62 Dalej parę nieczytelnych słów.

63 Chodzi o pułkownika Jana Wroczyńskiego, późniejszego generała Wojska Polskiego. Szerzej o generale Wroczyńskim: M. Wrzosek, Wojny o granice Polski Odrodzonej 1918-1921, Warszawa 1992.

64 Imienia podporucznika Szulborskiego nie udało się ustalić.

65 Imienia porucznika Brzozowskiego nie udało się ustalić.

66 Imienia żołnierza Barszczewskiego nie udało się ustalić.

67 Imienia porucznika Kozłowskiego nie udało się ustalić.

68 Nie udało się odczytać pełnego nazwiska.

69 Imienia chorążego Michalewskiego nie udało się odczytać.

70 Imienia doktora Borkowskiego nie udało się odczytać. 
71 Imienia podoficera Kamińskiego nie udało się odczytać.

72 Imienia chorazżego Żakiewicza nie udało się ustalić.

73 Imienia podpułkownika Ojrzanowskiego nie udało się ustalić.

74 Imienia porucznika Szwede nie udało się ustalić.

75 Imienia doktora Mazurkiewicza nie udało się ustalić.

76 Imienia doktora Gorczyńskiego nie udało się ustalić.

77 Imienia porucznika Średzińskiego nie udało się ustalić.

78 Imienia żołnierza Kolarskiego nie udało się ustalić.

79 Imienia inżyniera Zubelewicza nie udało się ustalić.

80 Imienia chorążego Kreczmara nie udało się ustalić.

81 Imienia chorążego Szalkiewicza nie udało się ustalić.

82 Imienia kapitana Pieczkowskiego nie udało się ustalić.

83 Imienia urzędnika Zamecznika nie udało się ustalić.

84 Imienia podoficera Szukaczuka nie udało się ustalić.

85 Imienia szeregowca Bociana nie udało się ustalić.

86 Imienia autora opracowania porucznika Mieszkowskiego nie udało się ustalić. 